
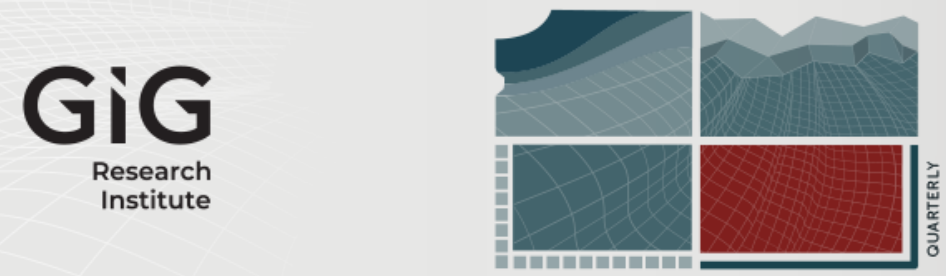

JOURNAL

OF

SUSTAINABLE

MINING

Volume 20 | Issue 4

Article 5

2021

\title{
Sources and techniques of domestic heating within TRITIA region
}

Author(s) ORCID Identifier:

Małgorzata Wysocka (iD) 0000-0002-1538-1294

Krzysztof Samolej (iD 0000-0002-0867-7556

Krystian Skubacz (D) 0000-0001-6858-7774

Follow this and additional works at: https://jsm.gig.eu/journal-of-sustainable-mining

Part of the Explosives Engineering Commons, Oil, Gas, and Energy Commons, and the Sustainability Commons

\section{Recommended Citation}

Wysocka, Malgorzata; Skubacz, Krystian; and Samolej, Krzysztof (2021) "Sources and techniques of domestic heating within TRITIA region," Journal of Sustainable Mining: Vol. 20 : Iss. 4 , Article 5.

Available at: https://doi.org/10.46873/2300-3960.1330

This Review is brought to you for free and open access by Journal of Sustainable Mining. It has been accepted for inclusion in Journal of Sustainable Mining by an authorized editor of Journal of Sustainable Mining. 


\title{
Sources and techniques of domestic heating within TRITIA region
}

\begin{abstract}
The paper presents the balance of energy consumption for domestic heating in Opole and Silesian Voivodship (Poland), divided into various media. The report was based on an analysis of approximately 250 documents containing low-carbon economy plans for individual municipalities (gminas). The authors compared the current situation in these voivodships and their districts with the structure of the heating system in Poland as a whole, based on data from the Central Statistical Office of Poland. The data demonstrate that the use of coal-based energy media has not changed significantly over the years and around $55-60 \%$ of households with individual heating systems use this type of media. A much more favourable trend is found in large urban centres, where there is a high proportion of district heating. The most common of the lower-emitting fuels (LPG, natural gas, electricity, heat pumps) is natural gas, and the share of the remaining sources within this group are barely significant.
\end{abstract}

\section{Keywords}

Air pollution, Households, Energy commodities, Tritia region, domestic heating

Creative Commons License

(c) (i)

This work is licensed under a Creative Commons Attribution 4.0 License. 


\title{
Sources and techniques of domestic heating within TRITIA region
}

\author{
Małgorzata Wysocka*, Krystian Skubacz, Krzysztof Samolej
}

Central Mining Institute, Silesian Centre for Environmental Radioactivity, Poland

\begin{abstract}
The paper presents the balance of energy consumption for domestic heating in Opole and Silesian Voivodship (Poland), divided into various media. The report was based on an analysis of approximately 250 documents containing low-carbon economy plans for individual municipalities (gminas). The authors compared the current situation in these voivodships and their districts with the structure of the heating system in Poland as a whole, based on data from the Central Statistical Office of Poland. The data demonstrate that the use of coal-based energy media has not changed significantly over the years and around $55-60 \%$ of households with individual heating systems use this type of media. A much more favourable trend is found in large urban centres, where there is a high proportion of district heating. The most common of the lower-emitting fuels (LPG, natural gas, electricity, heat pumps) is natural gas, and the share of the remaining sources within this group are barely significant.

The detailed data on the structure of sources and heating techniques in households presented in this study were used to create a model of pollution dispersion in the AirTritia project, which covered the part of the Czech, Polish and Slovak borderland forming the Tritia functional area.
\end{abstract}

Keywords: air pollution, households, energy commodities, Tritia region, domestic heating

\section{Introduction}

A ccording to World Health Organization, air pollution represents the biggest environmental risk to health. It is assessed, that about 3 up to 4,2 million deaths are attributable yearly to outdoor and indoor air pollution. Air pollution accounts for death due to stroke, heart disease, lung cancer, acute and chronic respiratory diseases. Due to the weighty concern of the problem, global organizations issued documents to help to monitor the air pollution and prepared guidelines to improve air quality and health of the inhabitants of the most affected areas [1,2]. The European Environment Agency publishes a yearly reports on the air quality in Europe, to analyze the state and trends of air pollutants emissions, concentrations and exposure of both population and ecosystems. On the other hand reports summarizing international projects assess methods of monitoring and estimating health impacts of air pollution [3-5]. The reduction of air pollution is also an economic challenge, especially in countries where the energy economy is based on hard coal and lignite. That's why WHO issued the document that describes and discusses the topic of air pollution from a health in all policies perspective. The report reflects the best available evidence from a health, economics and policy point of view and identifies future research areas and policy options [6]. Individual countries struggle with a different scale of the problem of air pollution. The share of pollution sources is changing, from combustion of coal and biomass, through industrial and agricultural emissions from transport. In order to better understand the phenomena of air pollution emission, dispersion, migration and health impact, different visual approaches are created on the base of existing data [7-9]. In the papers of authors from around the world various sources of pollution, their geographic location and factors influencing crossborder transport are analyzed [10-15]. Researchers investigate the problem of air pollution from the

Received 5 July 2021; revised 6 September 2021; accepted 6 October 2021.

Available online 30 December 2021

* Corresponding author.

E-mail address: mwysocka@gig.eu (M. Wysocka). 
a

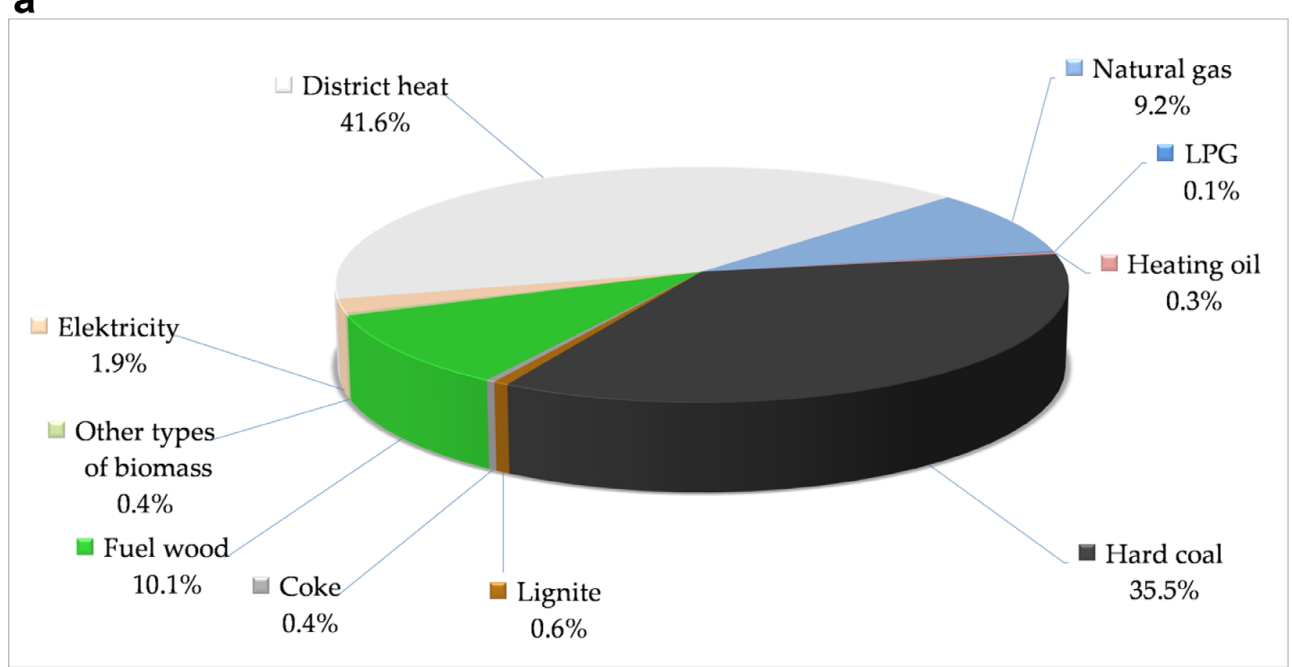

b

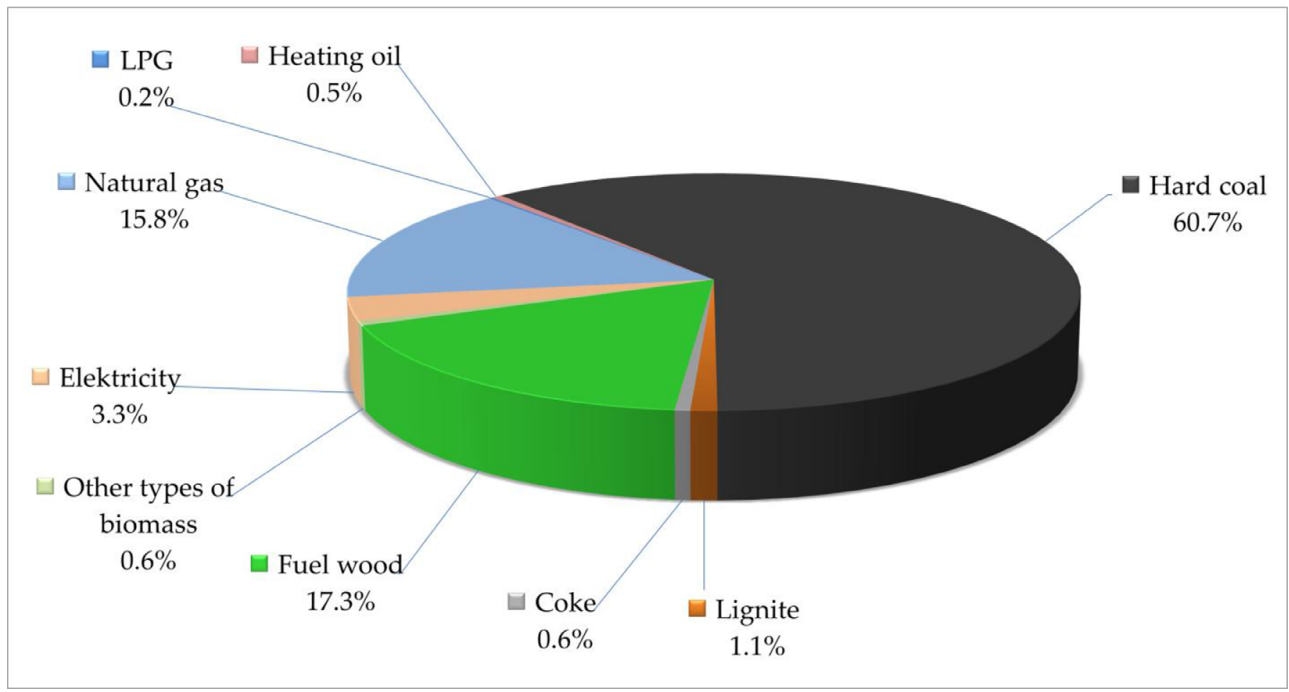

Fig. 1. a. Households in Poland in 2015 using various energy commodities for heating purposes [58]. b. Households in Poland in 2015 using various energy commodities for heating purposes - without district heat [58].

perspective of the entire globe, continents, regions or selected cities [16-19]. In both developed and developing countries, air pollution remains high, especially in industrial, densely populated areas. However, French researchers showed the possibility of changing the trend of air pollution. They stated that maintaining the level of fine dust contamination in accordance with the World Health Organization guidelines, in particular specific local conditions, always results in the decrease of the mortality of the population [20].

The region where air pollution is particularly high is Central Europe, including the Polish-Czech border. Researchers point out the sources of pollution and monitor the changes over time. According to Pokorná et al. [21,22] major source types in the mid-1990s were ascribed to coal and oil combustion, transport and resuspended dust. The highest air pollution in this part of Europe occurs in the following areas:

- the border area of Czech Republic, German and Poland, due to brown coal combustion,

- the Moravia-Silesia region at the Czech-Polish border - black coal combustion,

- Slovakia, Austria, Hungary, and the Balkans due to the use of heating oil.

The authors claim that the declining trend of concentrations of air contamination and change in the source pattern of the background of fine particles (PM2.5) in Central Europe reflects the economic 
a

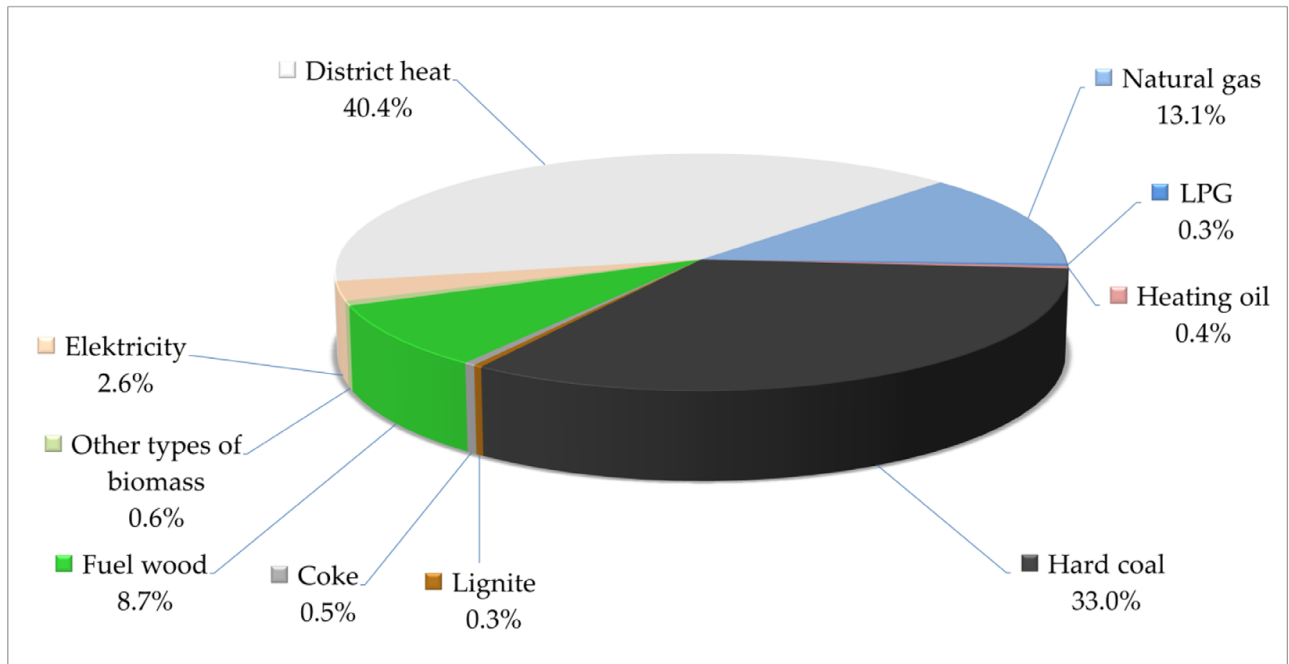

b

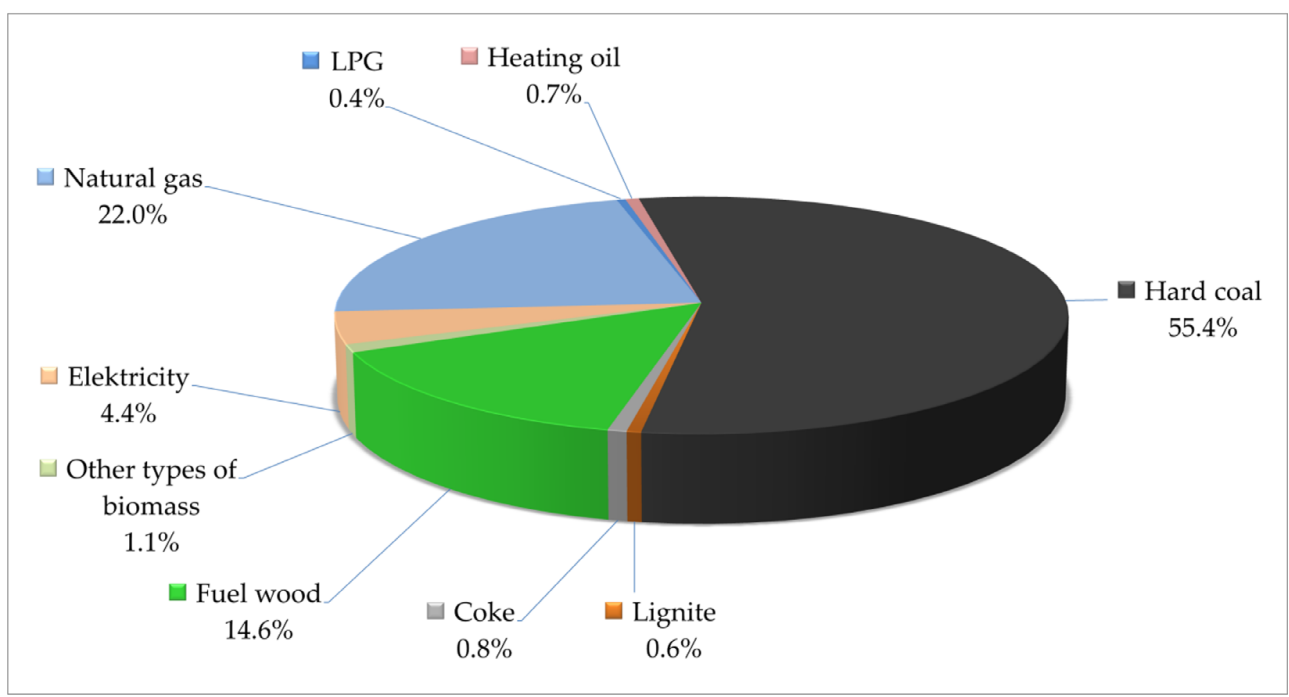

Fig. 2. a. Households in Poland in 2018 using various energy commodities for heating purposes [59]. b. Households in Poland in 2018 using various energy commodities for heating purposes - without district heat [59].

transformation and impact of legislation in Central Europe. Moreover the Czech scientists emphasize that in some rural areas of this part of Europe high concentration of the PM2.5 elements is due to the combustion in local heating boilers.

Research on air pollution and the share of industrial and other sources of pollution is also carried out in Poland [23-29]. Investigations conducted in Poland as in the world [30] confirm that elements released to the atmosphere from the combustion of solid fuels in residential sector may pose substantial risk to human health. According to Majewski and Rogula-Kozłowska [31] even in capital city Warsaw, coal and biomass combustion accounts for nearly $18.4 \%$ of fine PM.Therefore reducing emission of air pollution in this sector is urgent. There are numerous review of evidence of the health effects of black carbon (BC) (WHO [32-36]), emitted, among others, from home furnaces [37].

The use of fuel-burning combustion appliances can be a source of indoor air pollution. The combustion products of concern are particular matter, carbon monoxide and nitrogen dioxide. The air quality within and around buildings affects the health of the inhabitants. Health effects from indoor air pollutants may include irritation of the eyes, nose, and throat, headaches, dizziness, and fatigue. The long-term effects, can include for example some respiratory diseases, heart disease and cancer. WHO issued in 2015 report entitled Residential heating with wood and coal: health impacts and policy options in Europe and North America [38]. The report 
a

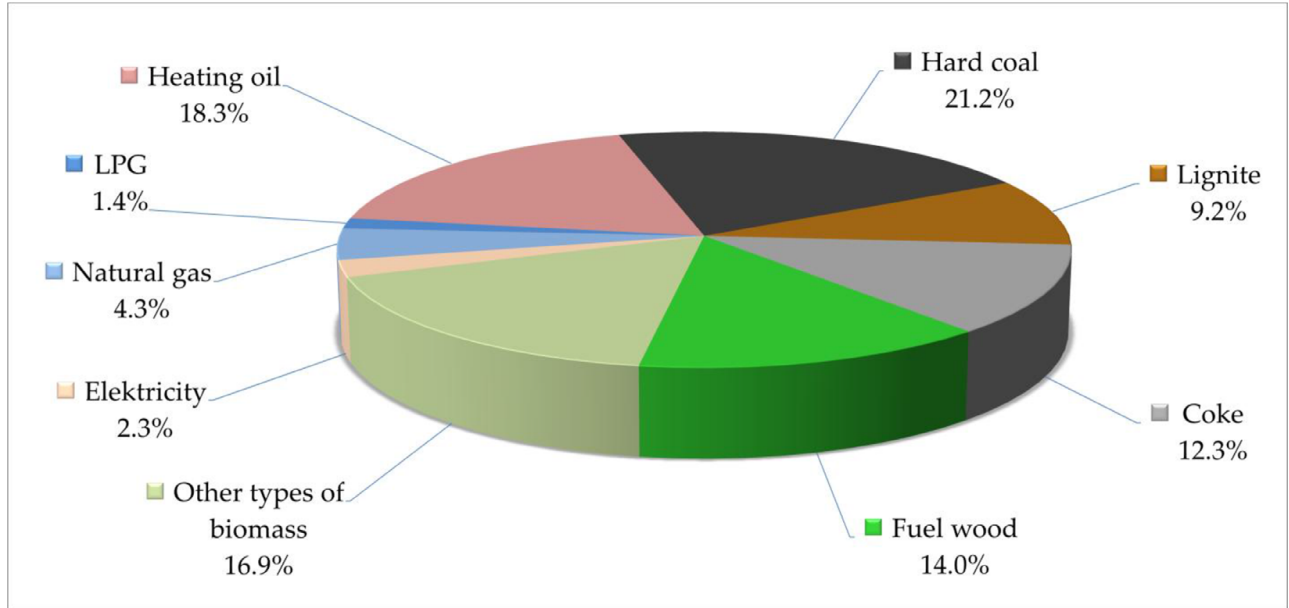

b

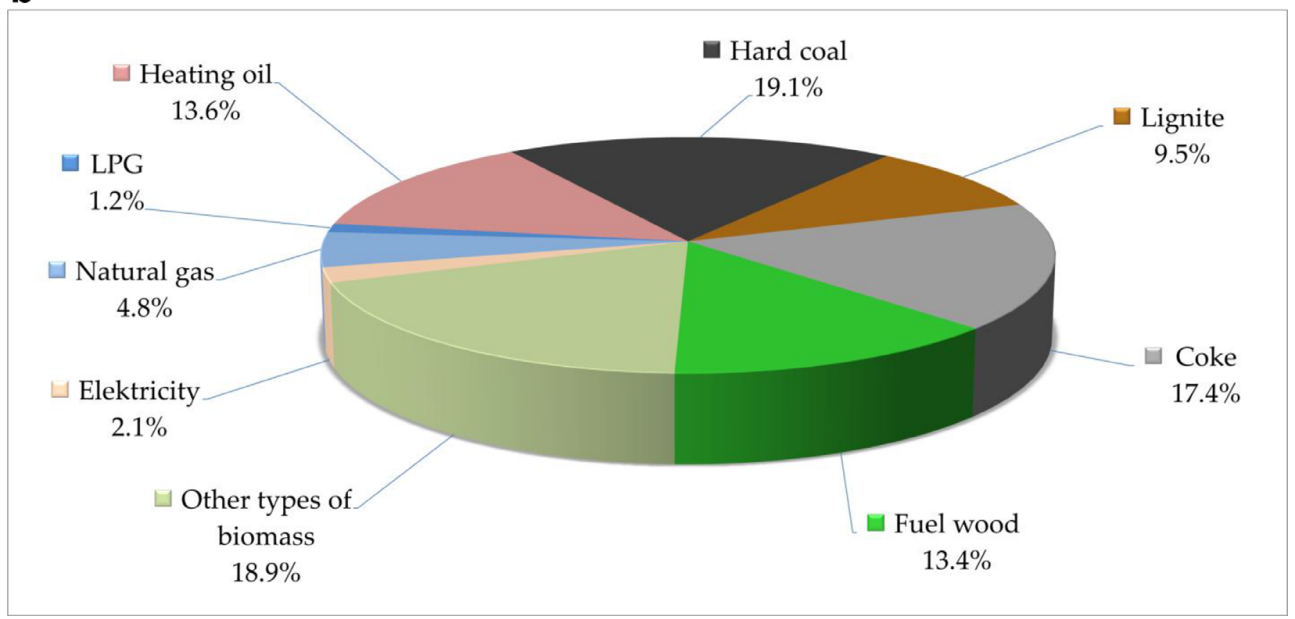

Fig. 3. a. Energy consumption in households in Poland in 2015 using various energy commodities - without district heat [58]. $b$. Energy consumption in households in Poland in 2018 using various energy commodities - without district heat [59].

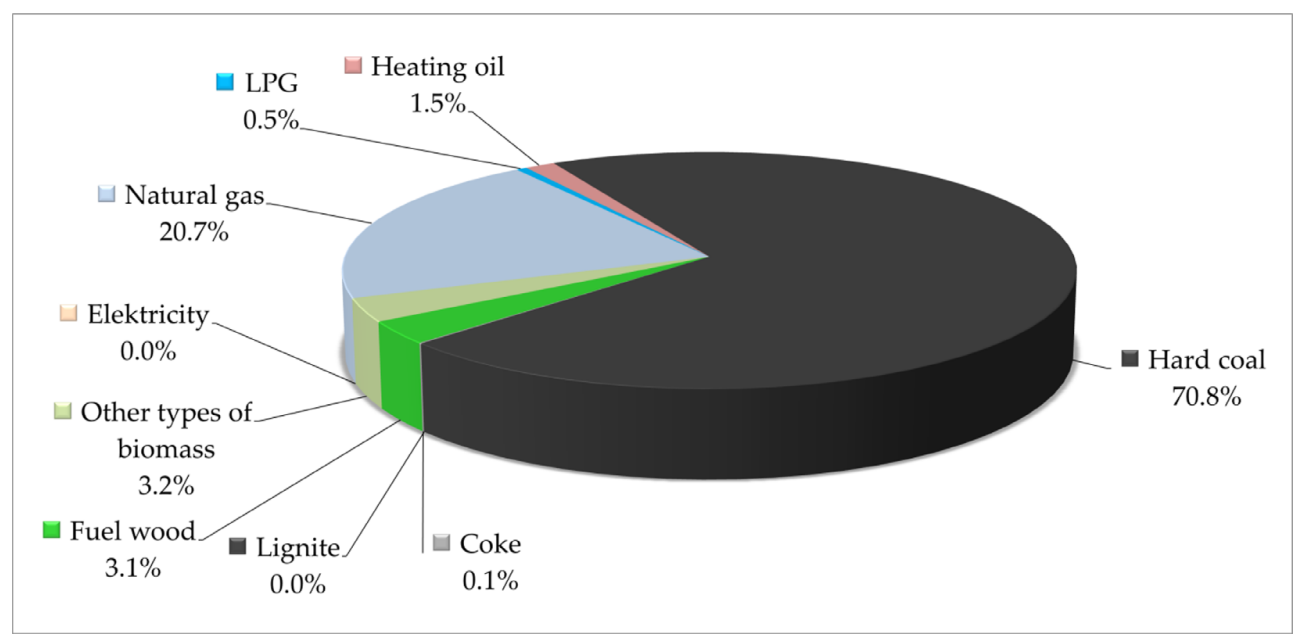

Fig. 4. Upper Silesia District. Energy consumption in households using various energy commodities, 2015. 


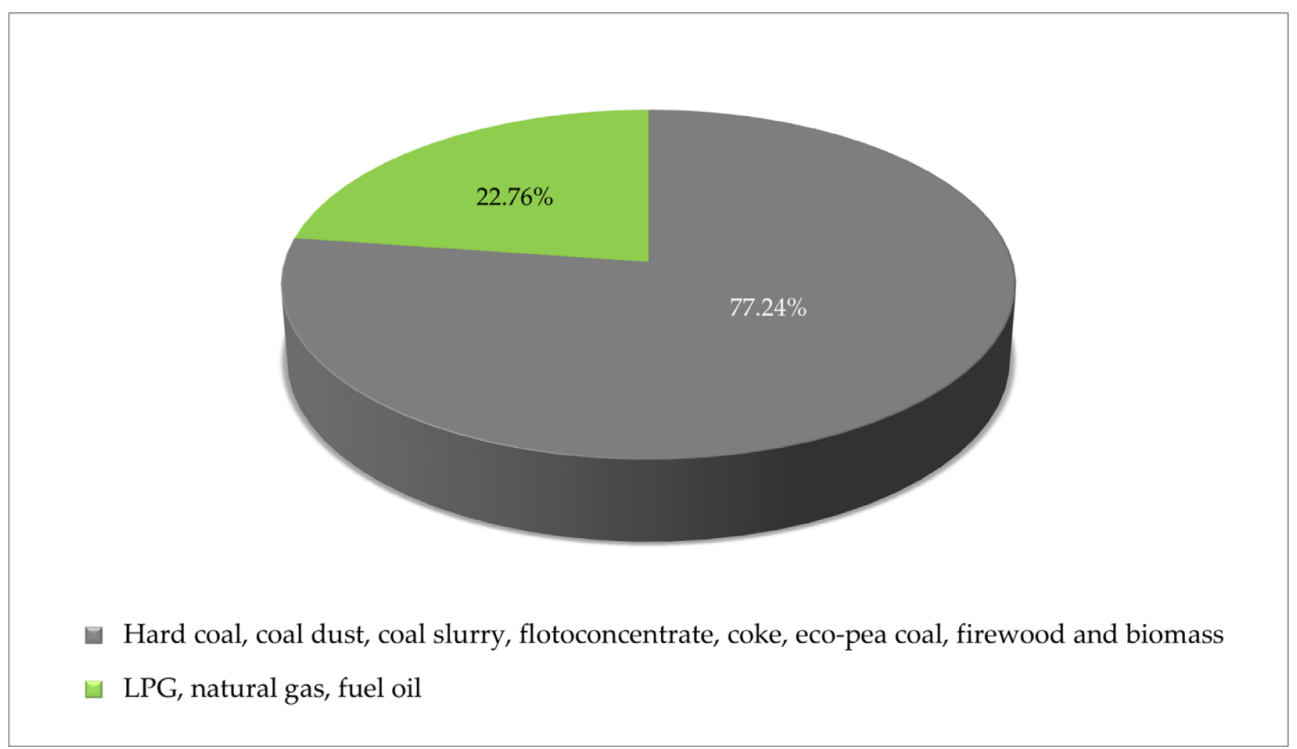

Fig. 5. Share of sources in energy consumption for heating households in Silesia Voivodship.

describes the health effects of residential heating with coal and wood in Europe and the United States. Morawska and co-authors claim that $10-30 \%$ of the total burden of disease from PM exposure is due to poor quality of indoor air. Therefore, exposure to fine and ultra fine particles due to indoor sources is likely to be one of the most important environmental factors affecting human health globally [39]. Research on indoor air quality with regard to the problems caused by coal and wood combustion, is carried out around the world [40]. For example in China extensive research on associations between different types of coal use, indoor air pollutants and immunologic/inflammatory markers were performed [41]. Jang and Smith in an alarming report from China state that indoor air pollution from solid fuel use is responsible for approximately 420,000 premature deaths annually [42]. Some studies have focused on estimating the health benefits of reducing the combustion of solid fuels [43].

Special attention is paid to the problem of children's health, especially sensitive to air pollution [44-50]. The epidemiological evidence from different part of world are focused on the association between outdoor and indoor exposure to solid fuel combustion and adverse respiratory effects in children. However researchers claim that findings from many reviews indicate that measurements and definitions of exposures and outcomes are unclear, need standardization, extended investigation, especially in low- and middle-income countries [51-54]. Indoor pollution research is also conducted in Poland, especially in the area of Upper Silesia,

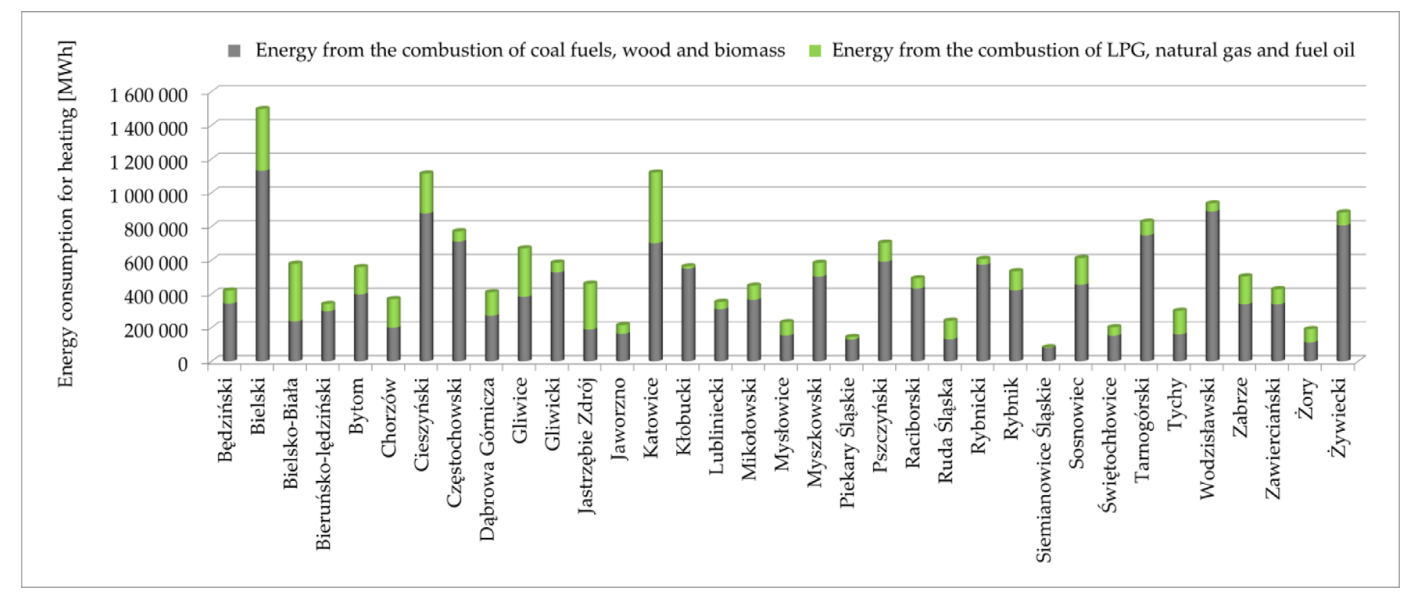

Fig. 6. Energy consumption for heating in gminas of Silesian Voivodship. 


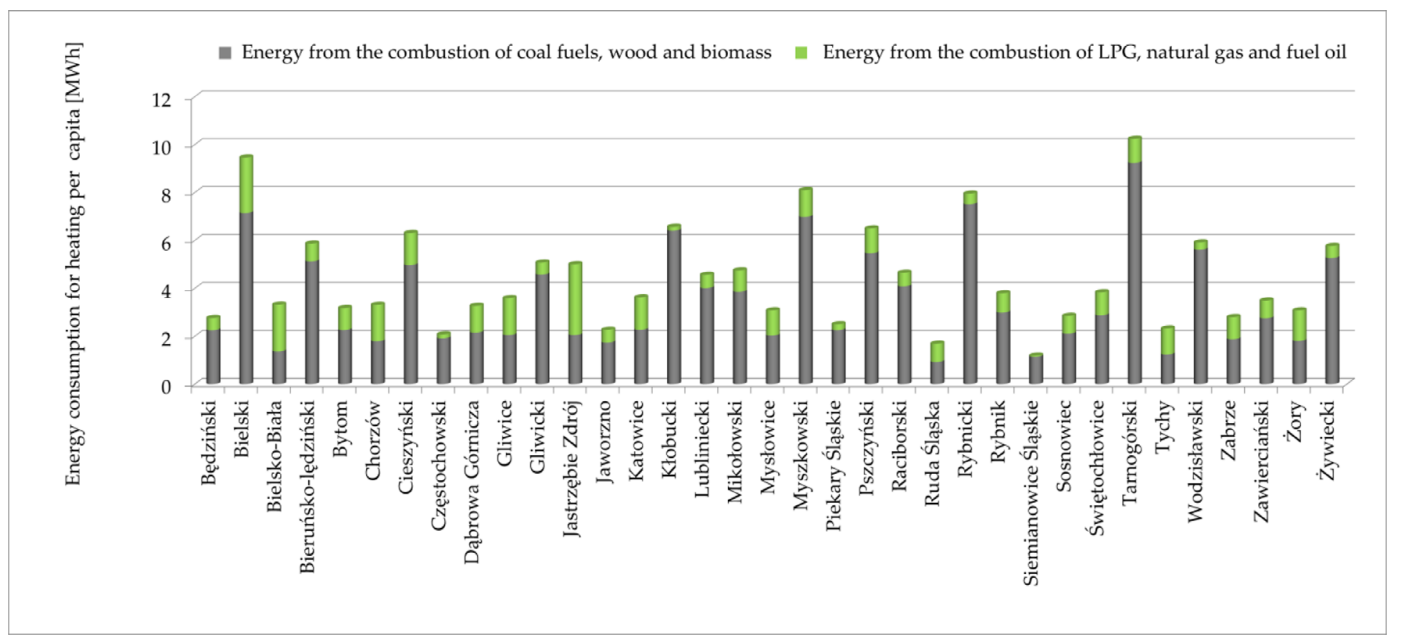

Fig. 7. Energy consumption for heating per capita in districts of Silesia Voivodship.

where most households use hard coal, often of low quality [55]. The results obtained by Błaszczyk et al. indicated that PM and other pollutants occurring both indoor and outdoor of kindergartens in Silesia, are an important source of children's exposure to genotoxic agents. They recommend changing coal stoves to electric or gas ones [56].

The Intergovernmental Panel on Climate Change, operating since 1988 under the auspices of the United Nations, published its fifth report on Earth's climate change in 2014. It states unequivocally that greenhouse gas emissions resulting from human activity contribute to climate change. The Member States of the European Union have adopted the socalled energy and climate package, which, among other things, indicates the need to reduce greenhouse gas emissions by $20 \%$.

Following this, the National Programme for LowEmission Economy Development was adopted in
Poland, with the main objective of developing a lowemission economy, understood as activities aimed at economic development and improvement of living conditions of people in gminas. The main claim of the document relates to the assumption that local actions satisfy low-carbon principles. The development of a low-carbon economy is possible if the necessary knowledge, gathered from information provided by municipalities, is available on:

- the location and amount of energy we use, and the sources from which it is obtained,

- measures that we can implement to use energy more efficiently and emit fewer greenhouse gases,

- renewable energy sources can be used to produce energy.

In 2013-2015, gminas developed Low Carbon Economy Plans (LCEP), which are documents that

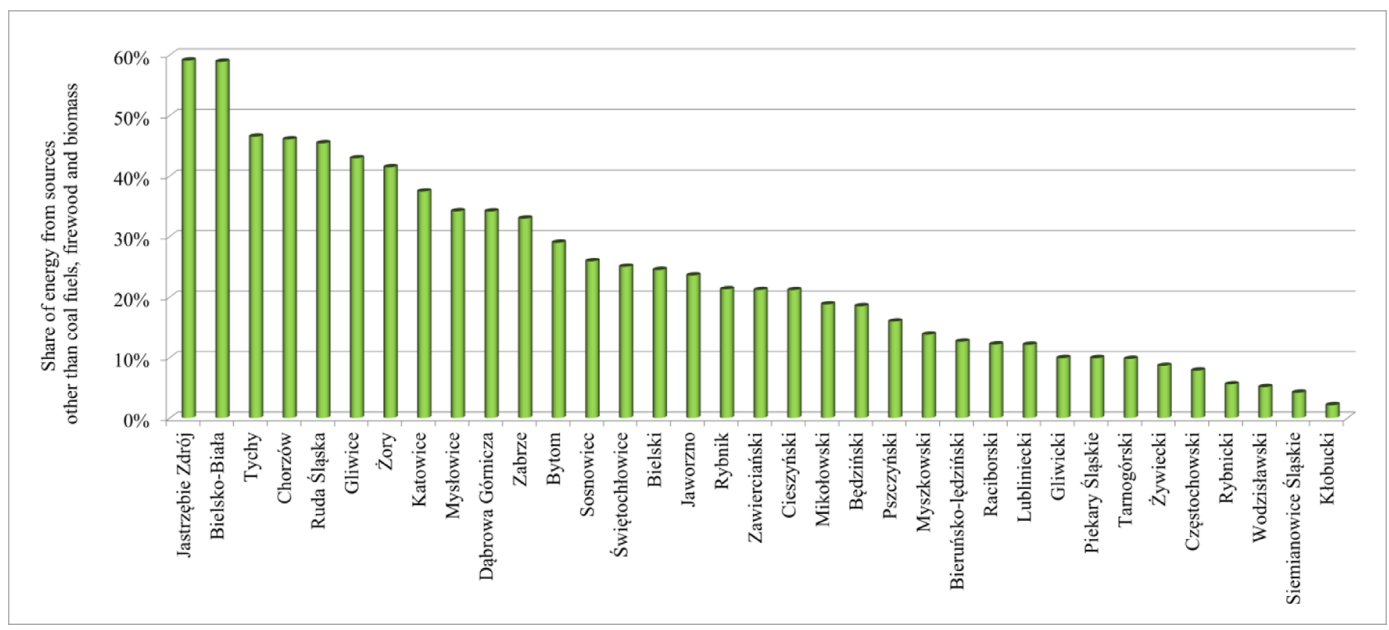

Fig. 8. Share of energy from sources other than coal fuels, firewood and biomass in individual districts of Silesia Voivodship. 


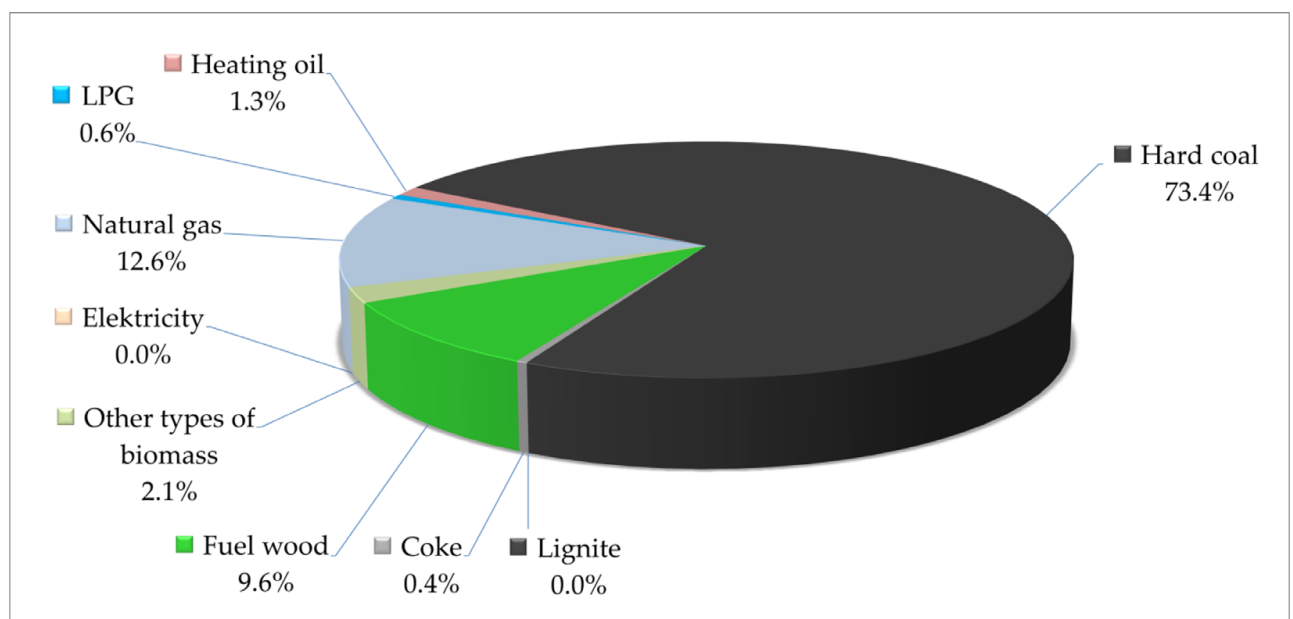

Fig. 9. Opole district, 2015. Energy consumption in households using various energy commodities.

detail the methods for reaching a low carbon economy at a local level. They identify, inter alia, the specific measures that local authorities and possibly private sectors will undertake to meet th targets set out in the adopted climate and energy package by 2020:

- reducing greenhouse gas emissions,

- increasing the share of energy from renewable sources,

- improving energy efficiency,

- improving air quality in areas where exceedances of air quality limits have been registered and air protection programmes (APP) and shortterm action plans (SHAP) are implemented.
The Polish-Czech-Slovak border region has for years been among the leading European areas in terms of bad ambient air quality. This is primarily the result of coal and coal products being burned in households for heating purposes, which is also associated with greenhouse gas emissions. This paper presents the results of an inventory of low emission sources (municipal emissions) in the Polish part of the TRITIA area, i.e. the Polish-CzechSlovak border region, covering the Silesian and Opole Voivodeships. The work was carried out within the framework of the project called AIR TRIRIA (Unified Approach to Air Pollution Management for Functional Urban Areas in the TRITIA Region). The primary objective was to develop an

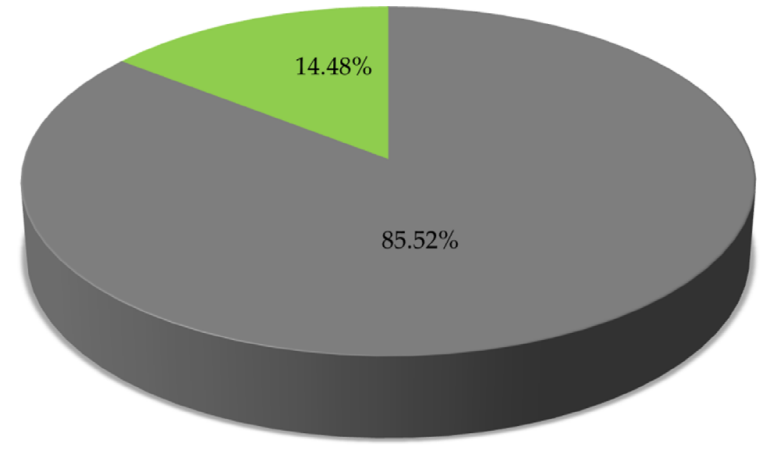

Hard coal, coal dust, coal slurry, flotoconcentrate, coke, eco-pea coal, firewood and biomass

घ LPG, natural gas, fuel oil

Fig. 10. Share of sources in energy consumption for domestic heating in Opole Voivodship. 


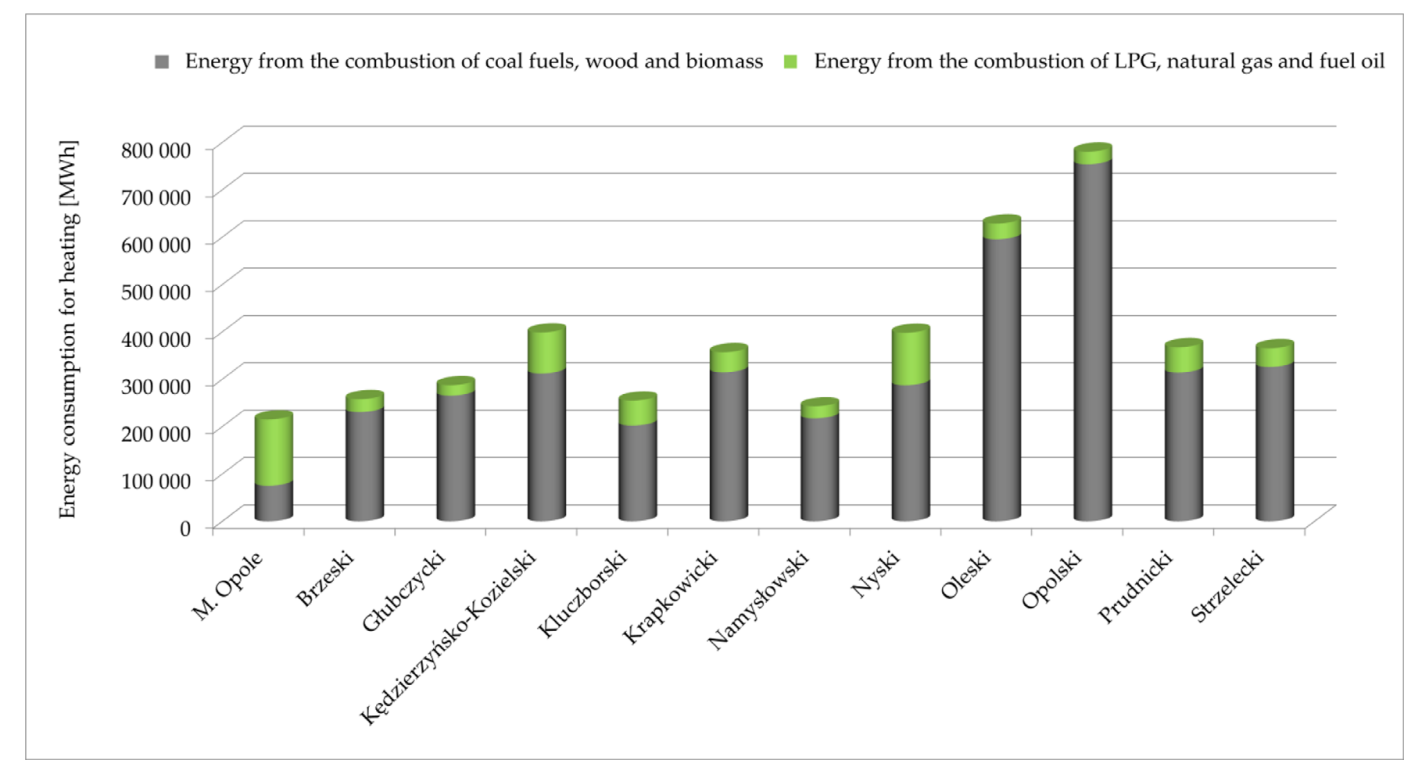

Fig. 11. Energy consumption for domestic heating in districts of Opole Voivodship.

effective method of air quality management at the regional level of the Czech Republic, Poland and Slovakia, with the potential to apply solutions also in other countries of the European Community with similar environmental problems.

\section{The method}

An inventory of energy media used for heating residential buildings and heating techniques applied was based on Low Emission Management Plans of individual gminas of Silesian Voivodeship (177 documents) and Opole Voivodship (71 documents).

In their Low Emission Management Plans, gminas present the main sources of air pollution in their areas. Particular emphasis is placed on assessing the impact of emissions from diffuse sources from domestic boiler rooms and furnaces (so-called low emissions). The data collected were presented separately for each powiat in Opole and Silesia Voivodeships and total for both voivodships.

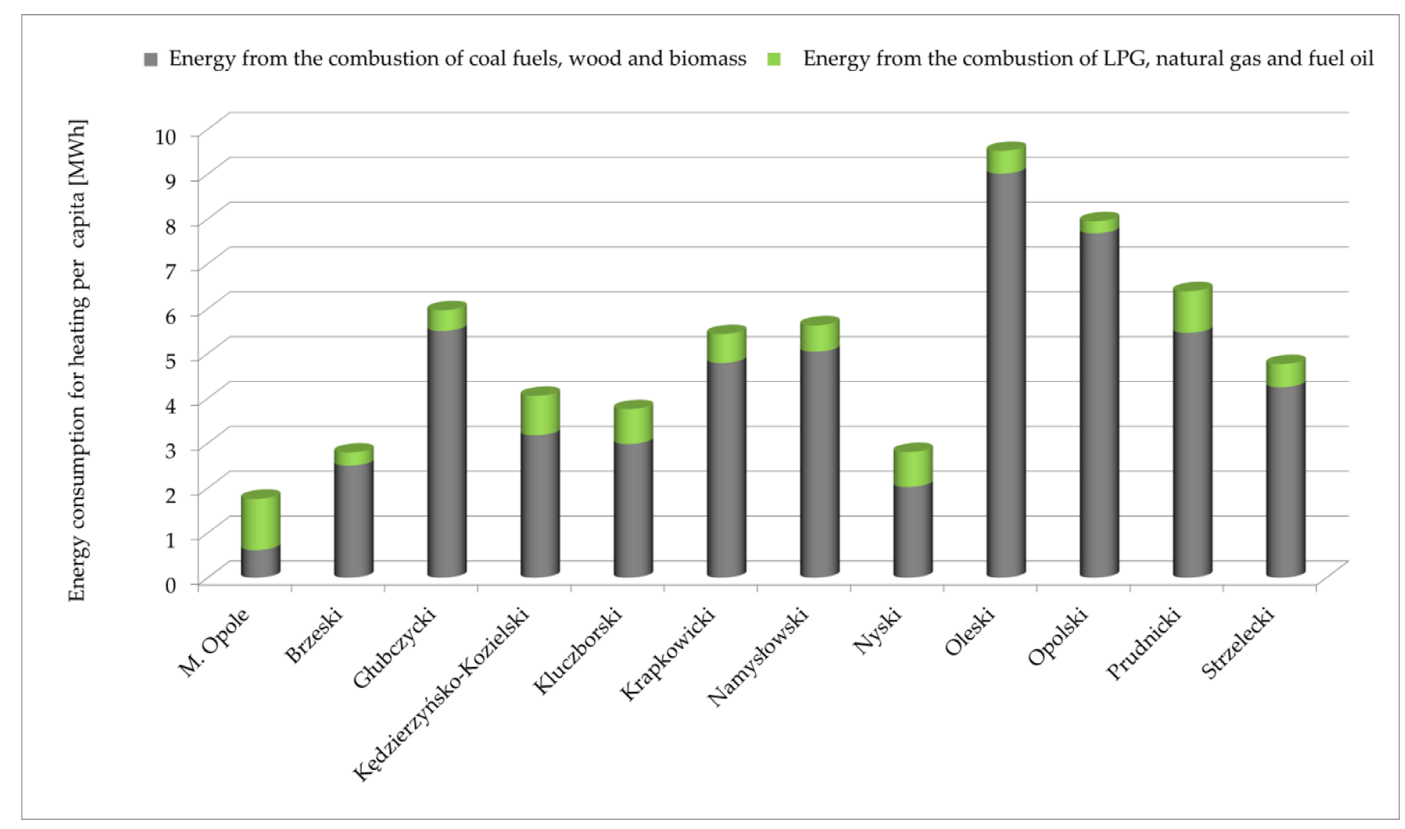

Fig. 12. Energy consumption for heating per 1 inhabitant in districts of Opole Voivodship. 


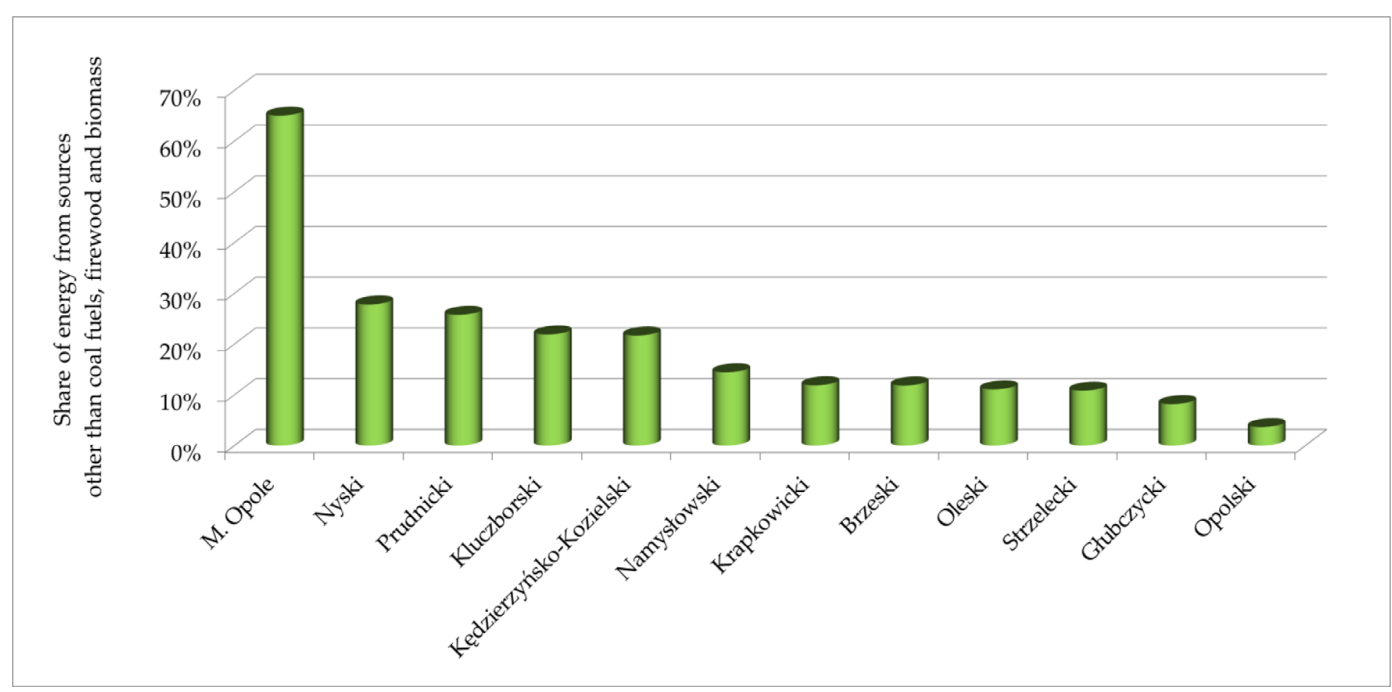

Fig. 13. Share of energy from sources other than coal fuels, firewood and biomass in individual districts of Opole Voivodship.

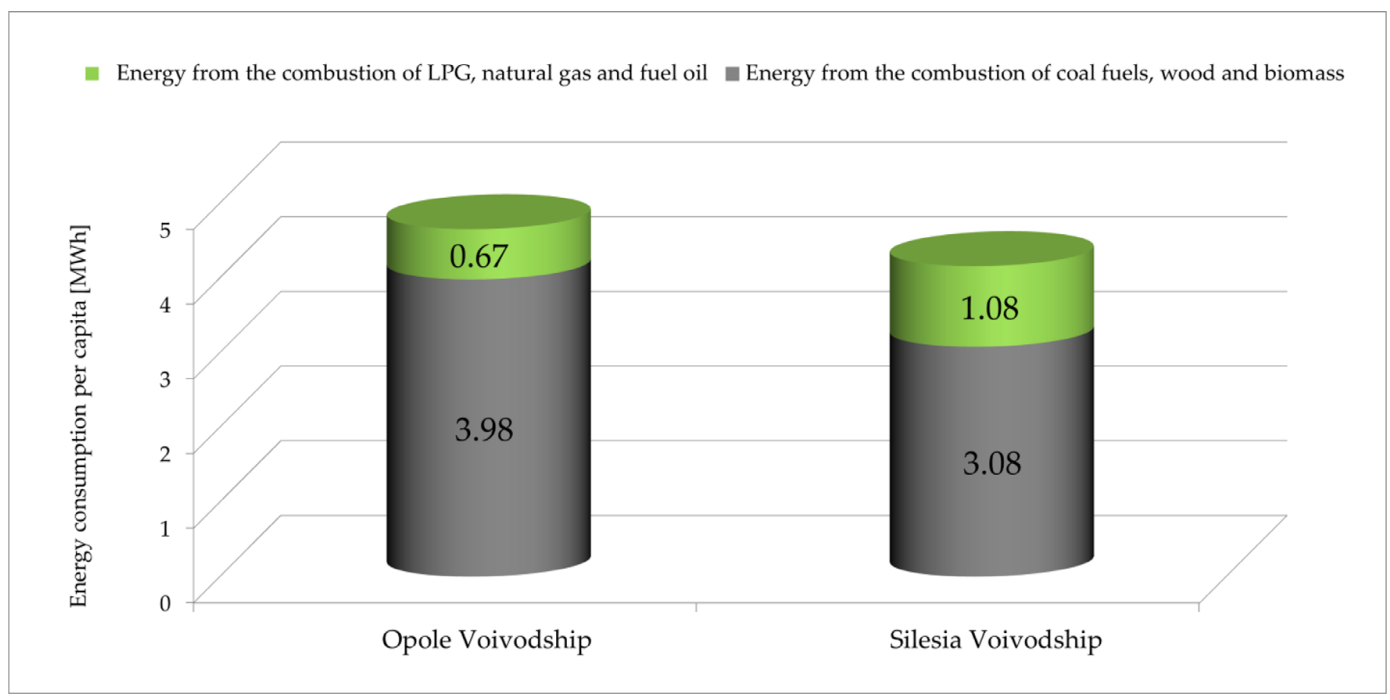

Fig. 14. Comparison of energy consumption from different sources for domestic heating in Silesia and Opole Voivodeships, per capita.

The plans for the individual gminas were prepared by different specialised companies based on surveys and available data on the consumption of energy media. This, therefore, did not affect the uniformity of the documents, which varied in quality and accuracy. This occasionally made it difficult to analyse them, especially when considering the heating techniques used.

Information on the situation in the gminas of the Silesia and Opole Voivodeships was compared with the situation in the whole country, using data provided by the Central Statistical Office of Poland in 2015 and 2018. Statistical data from 2015 makes it possible to compare the use of individual energy media in the voivodships of the TRITIA area with their use in the country as a whole. A comparison of statistics from 2015 to 2018 shows the trend of changes in the use of different energy sources in Poland.

\section{Inventory of low emission sources in the Polish part of the TRITIA area}

The greatest emission load on the atmospheric air in the border area was caused by combustion of solid fuels - hard coal, hard coal dust, hard coal slurry, flotation concentrate, coke, eco-pea coal, firewood and biomass. Many factors determine the amount of harmful emissions from the combustion of solid fuels, the most important of which are the type of fuel and its calorific value, the ash content and finally the efficiency of the device used for 


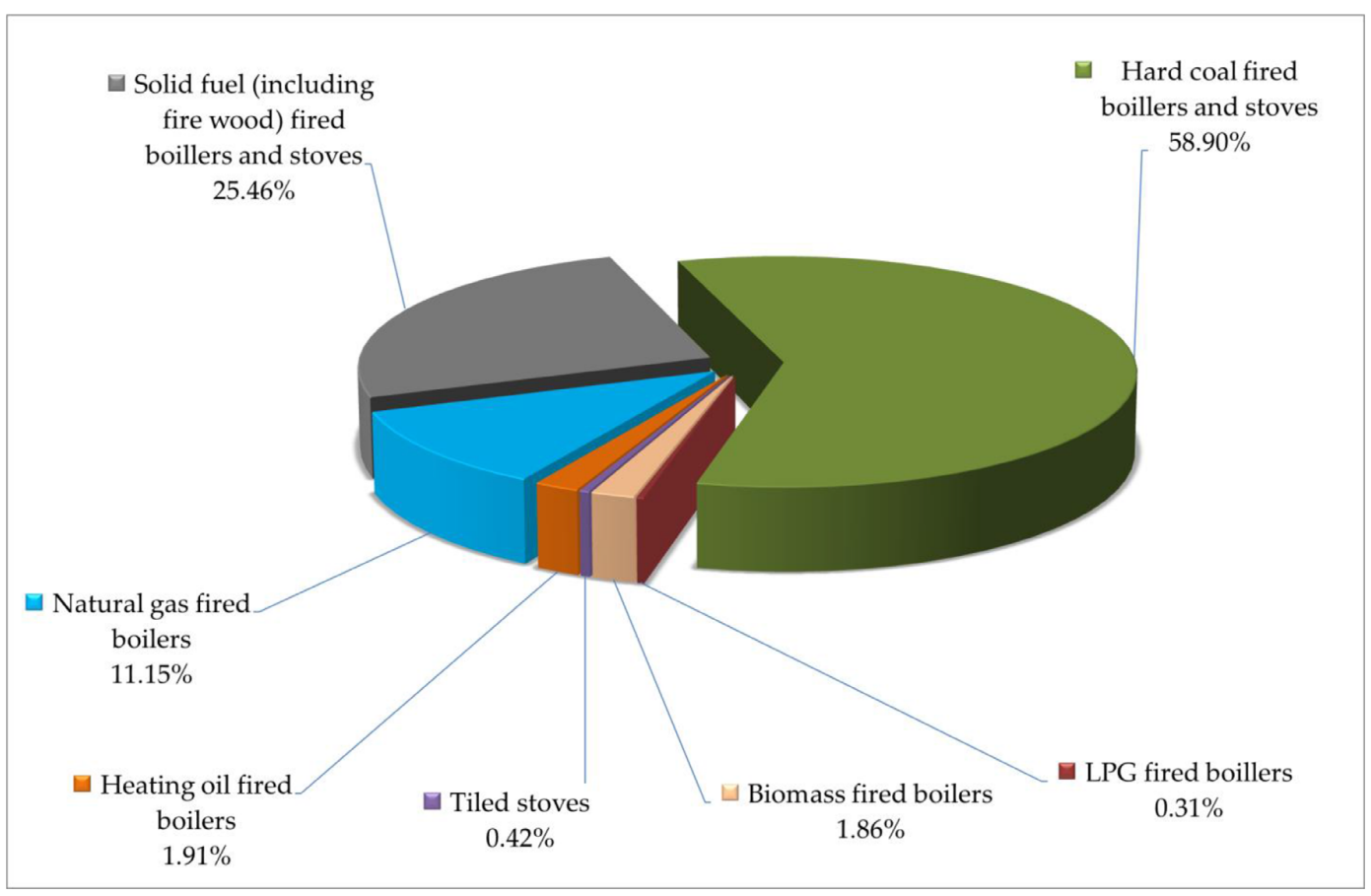

Fig. 15. Silesia District. Equipment of households with space heating appliances.

combustion [57]. Information on the situation in the gminas of Silesia and Opole Voivodeships was compared with the situation in the whole country. According to the Central Statistical Office (CSO), the primary source of energy in households in Poland is solid fuels [58].

Figs. $1 \mathrm{a}, \mathrm{b}$, and $2 \mathrm{a}, \mathrm{b}$ present the structure of energy consumption in households in Poland in 2015 and 2018, based on data compiled by the Central Statistical Office [58,59].

Analysing all dwelling types, in 2015 hard coal was used in $35.5 \%$ of all households (Fig. 1a). The share of lignite, coke and biomass was low, as these energy media were used in $1.4 \%$ of households. Network heat was used in almost $42 \%$ of households and natural gas in over $9 \%$. Only less than $2 \%$ used electricity. The share of other energy media such as solar panels, wind energy, heat pumps was negligible and was not included in the statistical summary. In order to trace the use of energy sources in detached houses, statistics are compiled, excluding district heating (Fig. 1b). It was assumed that district heating mainly heats collective buildings. The main fuels used for heating detached buildings, mainly single-family houses, were hard coal $(60.7 \%)$ and wood $(17.3 \%)$. The other energy media were used in slightly more than $20 \%$ of the buildings.

In 2018, slightly fewer households used hard coal. The number of all households using hard coal fell by $2.5 \%$. In detached buildings (not using district heating), the downward trend is higher: $5.3 \%$ fewer households used hard coal. Fewer households also used firewood, while natural gas and electric heating were used to a greater extent. In buildings not using district heating, the most significant change in the consumption structure of energy media was an increase of $6.2 \%$ in the number of households heated by natural gas.

Fig. $3 a$ and $b$ shows the percentage of energy consumption from each source in Poland, in households not using district heating, in 2015 and 2018. Consumption of fossil fuels (hard coal, lignite and coke) has increased slightly by $3.3 \%$. There has been a minor change in the degree to which individual fuels are used: the consumption of hard coal has decreased by around $2 \%$, while the consumption of coke has increased by around $5 \%$. The use of wood remained at a comparable level, while the use of other types of biomass increased. Electricity use is just over $2 \%$ of total energy consumption. The share of energy from renewable sources is marginal.

Data from LCEP documentation for individual gminas were used to gather information on the use of energy sources in Silesia and Opole Voivodeships. LCEP documents specify the fuels burned in more detail than the data provided by the Central Statistical Office in Poland. They estimate, for example, the share of coal-derived fuels such as 


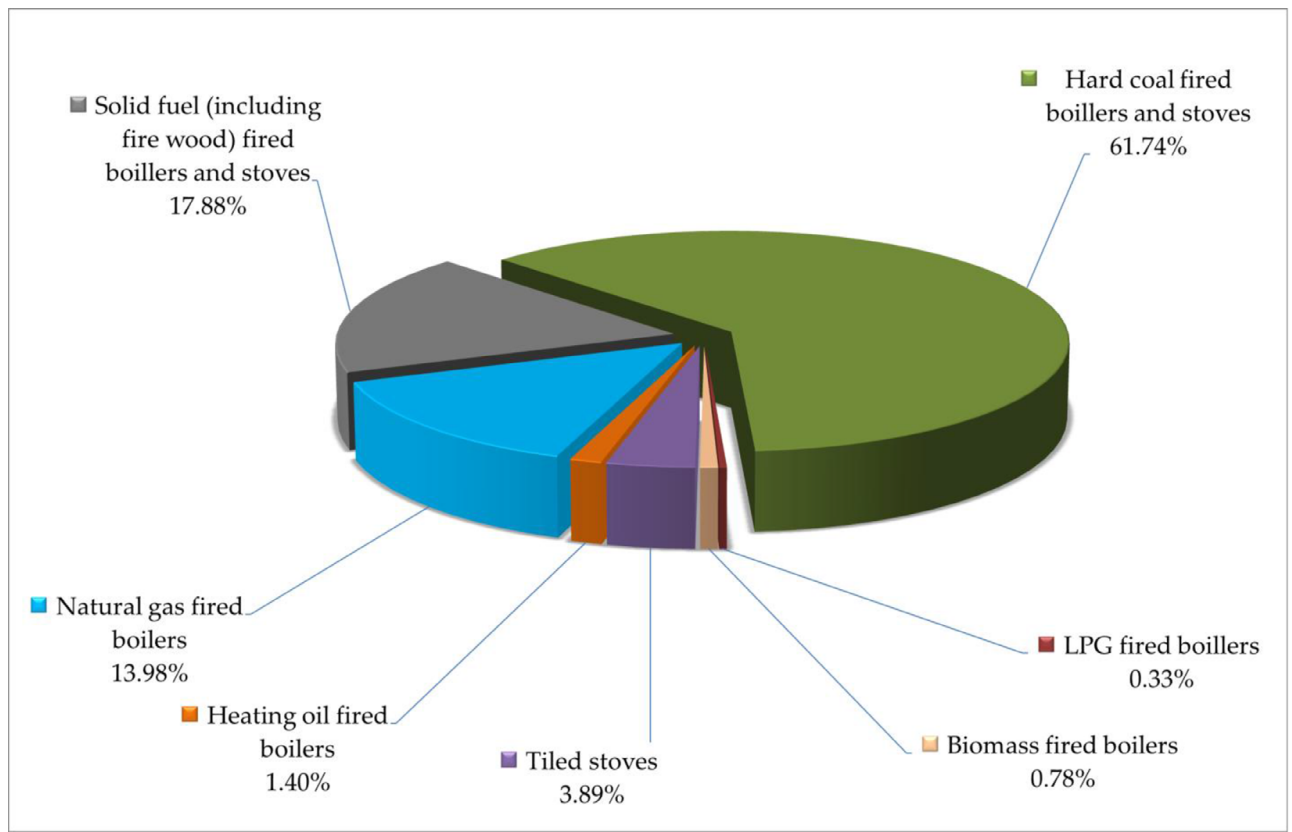

Fig. 16. Opole district. Equipment of households with space heating appliances.

slurry, dust, and enrichment waste - flotation concentrates. The data are important to understand the reasons for the poor state of air quality in the PolishCzech-Slovak border area. The 2016/2017 heating season was the last one in which slurry and flotation concentrates were allowed to be burnt. At present, these fuels must not be burned in domestic boilers because of high emissions of air pollutants, including heavy metals, compared to other coal fuels. Information on the use of low-quality coal fuels was included in the analysis presented, as they were still being used in Silesia and Opole Voivodeships during the project implementation years. Regulations implementing the Fuel Quality Monitoring and Control System Act [60], which aim to eliminate solid fuels unsuitable for domestic combustion from the market, were published in the Official Journal of Law on 04 October 2018 [61-64]. As a result of this legislation, fuels unsuitable for domestic combustion - coal slurry and flotation concentrate - have been eliminated from the retail market.

Fig. 4 presents the share of energy media in the total consumption of energy for heating homes in Silesia Voivodship, excluding district heating. Of the energy sources analysed, approximately $70 \%$ are coal and derived products and wastes from enrichment: coal dust $3.04 \%$, coal slurry $1.11 \%$ and flotation concentrate $0.14 \%$. The use of sludge, coal fines and flotation concentrates does not exceed $5 \%$. The share of these media in the total energy consumption in Silesia is therefore not high, but it should be remembered that low-quality coal fuels, often burnt in outdated cookers and boilers, contribute very significantly to air pollution emissions. Firewood, whose poor quality can also result in increased emissions of harmful agents during the combustion process, produces $3.14 \%$ of the energy used for heating homes. The share of energy from the use of lignite is insignificant.

Fig. 5 presents the structure of energy consumption for heating of households divided into two groups of energy media. The first group includes coal-based fuels (hard coal, hard coal dust, slurry, flotation concentrate, coke, eco-pea coal), firewood and biomass. The second group includes LPG, natural gas and fuel oil. In Silesia, the total amount of energy consumed to heat households using solid coal fuels, firewood and biomass is $77 \%$. Only about $23 \%$ of energy comes from sources that have a lower environmental impact - fuel oil, natural gas and LPG. The contribution of other sources to domestic heating, such as electricity or geothermal energy, for example, is negligible.

Energy consumption in individual powiats of Silesia Voivodeship varies considerably (Fig. 6). The differences are mainly due to the size of the district area, the number of inhabitants, the type and age of buildings and many other factors. It is evident that in rural powiats (such as Wodzisław, Kłobuck), the consumption of energy from fossil fuels is higher than in urban counties. This is probably since, in 
a

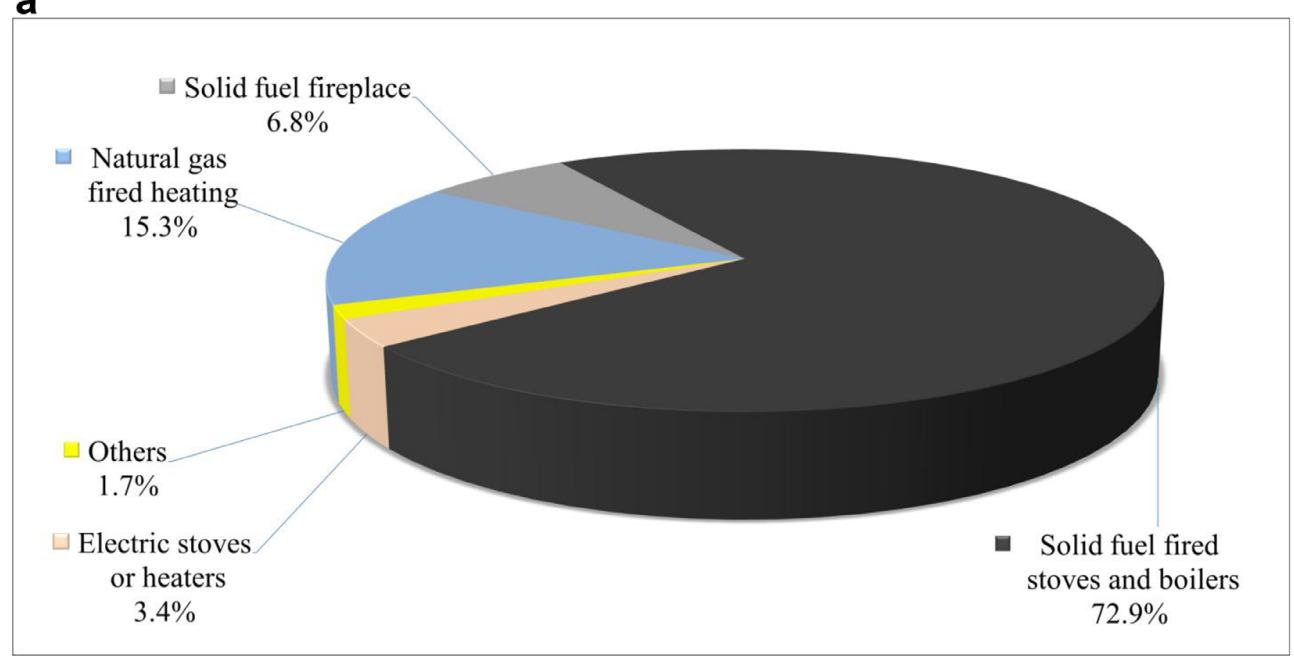

b

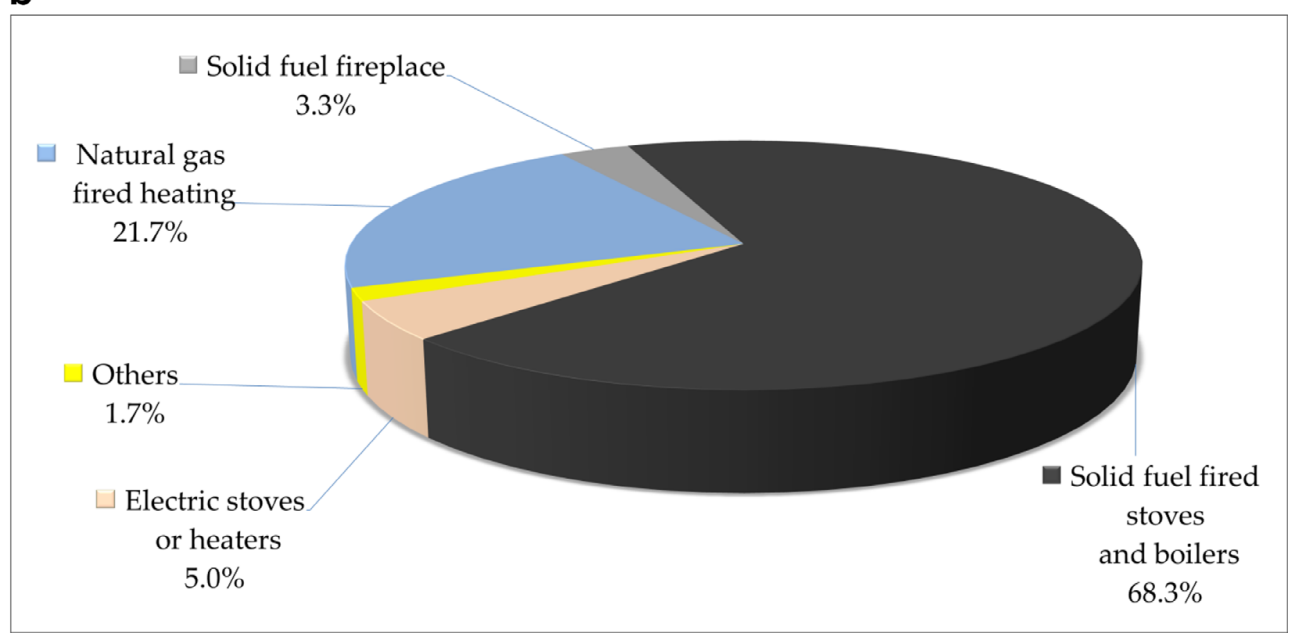

Fig. 17. a. Equipment of households in Poland with space heating appliance without district heat, 2015 [58]. b. Equipment of households in Poland with space heating appliance without district heat, 2018 [59].

cities, a large proportion of the population lives in block housing, where heat is supplied by a system, buildings are more often insulated, and the surface area of flats is smaller than in the case of singlefamily houses. The villages are dominated by singlefamily housing with a high proportion of old buildings that do not meet energy efficiency criteria. Fig. 7 shows energy consumption per capita in the counties of Silesia Voivodship. In rural powiats with predominantly dispersed housing, energy consumption per capita is significantly higher than in urban districts. The lowest energy consumption is in cities. In cities, the share of non-carbon energy and firewood is higher than in counties. The percentage share of energy from sources other than coal fuels and firewood in the total energy consumed for heating buildings in the districts of Silesia Voivodeship is shown in Fig. 8. The leaders in the use of energy media, the combustion of which emits less pollution into the air, are the cities. In five of them (Jastrzębie Zdrój, Bielsko-Biała, Dąbrowa Górnicza, Ruda Ślaska, Tychy and Gliwice) more than $50 \%$ of the energy consumed comes from non-carbon sources, which are less harmful to the environment. However, in as many as seven powiats the share of fuels other than coal does not exceed $10 \%$.

In Opole Voivodship, the share of hard coal in energy production for heating households is even higher than in Silesia Voivodship and amounts to $72.5 \%$ (Fig. 9). Adding together all coal fuels, including hard coal dust and slurries, coke, eco-pea coal as well as firewood and biomass gives $85.5 \%$ of the energy, while fuels such as fuel oil, natural gas, and LPG account for $14.5 \%$ (Fig. 10). Similarly to Silesia Voivodeships, the share of solar energy, wind energy, electricity, heat pumps and lignite is 
Table 1. The balance of substance production as a result of heating apartments in the Silesian voivodeship.

\begin{tabular}{|c|c|c|c|c|}
\hline Description & $\mathrm{SO}_{2}$ & $\mathrm{NO}_{x}$ & $\mathrm{CO}$ & $\mathrm{CO}_{2}$ \\
\hline Average production $\mathrm{kg} /$ (person·year) & 14.3 & 5.9 & 52.0 & 2374 \\
\hline $\begin{array}{l}\text { Percentage of the voivodeship popula- } \\
\text { tion for which the results were avail- } \\
\text { able }(\%)\end{array}$ & 4.3 & 4.3 & 3.9 & 2.3 \\
\hline $\begin{array}{l}\text { Estimated production of substances for } \\
\text { the entire voivodeship ( } \mathrm{Mg} / \text { year) }\end{array}$ & 82900 & 34200 & 302400 & 13812700 \\
\hline Population in the voivodship & 5820000 & & & \\
\hline
\end{tabular}

(based on Low Carbon Economy Plans).

negligible. The analysis of energy consumption in individual powiats illustrates that the total energy consumption in Opole Voivodship is lower than in Silesia Voivodship (Fig. 11), which is understandable given the differences in the populations of the two regions. Energy consumption per one inhabitant in none of the districts of Opole Voivodship is lower than $1 \mathrm{MWh}$, and in most districts, it ranges between 2 and $6 \mathrm{MWh}$. In Silesia Voivodship, in one city with powiat rights, energy consumption is lower than $1 \mathrm{MWh}$, and in most cases, it is between 2 and $4 \mathrm{MW} / \mathrm{h}$ (Fig. 12). Opole is the only powiat in which the share of fuels other than coal burned in households exceeds $60 \%$. In the remaining districts, the use of non-carbon media varies between about $4 \%$ and about $28 \%$ (Fig. 13).

Fig. 14 presents a comparison of energy consumption per capita concerning solid coal fuels, wood and other fuels in Opole and Silesia Voivodeships. Presumably, the reason for the differences in the structure of energy consumption in the two areas is the larger share of rural households and single-family housing in Opole Voivodship compared to Silesia Voivodship.

\section{Analysis of heating techniques in the Polish part of the TRITIA area}

The scale of emissions in the heating process is determined mainly by the type of device (heating technique) and its efficiency. Figs. 15 and 16 show the percentage share of individual heating units in households, excluding district heating. These diagrams were obtained based on the results of surveys obtained during the development of the LCEP. Unfortunately, not all LCEP documents contained full and comprehensive information. For example, these data were missing from Opole and Katowice. The vast majority of households that provided information on the heating techniques used to heat use coal-fired boilers. The share of coalfired boilers accounts for about $60 \%$ of all types of heating units in both voivodships. Solid fuel boilers, including wood and biomass, rank second in terms of percentage share. Although wood and biomass do not worsen the overall balance of carbon dioxide emissions into the atmosphere and consequently do not harm climate change, their combustion also causes more emissions than the combustion of fuels such as gas, fuel oil or LPG.

As the basic fuel used in both provinces for heating homes is hard coal, the share of coal-fired boilers in the structure of heating equipment is dominant. These are often old off-grade or class 3 and 4 boilers. Compared to class 5 boilers, class 3 boilers can emit up to around four times more dust, and class 4 boilers up to $50 \%$ more dust. Formally, since some time the sale of boilers with a nominal power of up to $500 \mathrm{~kW}$, intended for burning of solid fuels only, which meet the criteria specified for class 5 boilers, are permitted in Poland. This means for boilers with automatic fuel loading that the emission limit for $\mathrm{CO}_{2}$ is no more than $500 \mathrm{mg} / \mathrm{m}^{3}$, the emission limit for dust is no more than $40 \mathrm{mg} / \mathrm{m}^{3}$ and the emission limit for gaseous organic pollutants is no more than

Table 2. The balance of substance production as a result of heating apartments in the Opole Voivodship.

\begin{tabular}{|c|c|c|c|c|}
\hline Description & $\mathrm{SO}_{2}$ & $\mathrm{NO}_{x}$ & $\mathrm{CO}$ & $\mathrm{CO}_{2}$ \\
\hline Average production kg/(person·year) & 17.0 & 2.9 & 38.2 & 3175 \\
\hline $\begin{array}{l}\text { Percentage of the voivodeship popula- } \\
\text { tion for which the results were avail- } \\
\text { able }(\%)\end{array}$ & 1.5 & 1.5 & 1.5 & 1.5 \\
\hline $\begin{array}{l}\text { Estimated production of substances for } \\
\text { the entire voivodeship ( } \mathrm{Mg} / \text { year) }\end{array}$ & 16300 & 2800 & 36700 & 3046000 \\
\hline Population in the voivodeship & 959000 & & & \\
\hline
\end{tabular}

(based on Low Carbon Economy Plans). 
$20 \mathrm{mg} / \mathrm{m}^{3}$. However, it is difficult to forecast how quickly the share of class 5 boilers will increase in the structure of heating equipment over the next few years.

Fig. 17a and b shows CSO data from 2015 to 2018 (CSO, 2015; to compare the use of individual heating techniques in Silesia and Opole Voivodeships overall data from Poland [3]. In 2015, the share of coal-fired boilers was lower in Opole and Silesia Voivodeships than in the whole of Poland; the use of solid fuel boilers, including wood, was higher. In contrast, heating techniques using natural gas are much more common across Poland. It is worth noting that the use of natural gas is increasing nationally.

Combustion of coal causes not only $\mathrm{CO}_{2}$ emissions, but also other harmful substances such as $\mathrm{SO}_{2}, \mathrm{NO}_{\mathrm{x}}$ and CO. Tables 1 and 2 show the estimated values of the emissions of oxides in the Śląskie and Opolskie Voivodeships. Unfortunately, only a small number of municipalities (about 10\%) in their documents Low Carbon Economy Plans, provide data on the emission of $\mathrm{SO}_{2}, \mathrm{NO}_{x}, \mathrm{CO}$, and $\mathrm{CO}_{2}$ as the result of the heating of households, and therefore the information presented may not be representative for the entire TRITIA area.

Presently a lot of households still use the solid fuel fired boilers - see Figs. 14-17, and coal is the basic fuel used for heating flats in both voivodships. Often these are also non-class boilers or class 3 and 4 . Compared to class 5, class 3 boilers can emit up to about four times more dust, and class 4 boilers $-50 \%$ more dust. Formally, for some time in Poland it has been allowed to sell only such boilers with a nominal power of up to $500 \mathrm{~kW}$ intended for burning solid fuels that meet the criteria specified for class 5 . For boilers with automatic fuel loading, this means that the limit of CO emission is not more than $500 \mathrm{mg} / \mathrm{m}^{3}$, the limit value for dust emission is not more than $40 \mathrm{mg} / \mathrm{m}^{3}$, and the limit value for emission of gaseous organic pollutants is not more than $20 \mathrm{mg} / \mathrm{m}^{3}$. However, it is difficult to forecast how quickly the share of class 5 boilers in the energy balance will increase over the years.

Carbon dioxide $\left(\mathrm{CO}_{2}\right)$ is the most prominent of the greenhouse gases, therefore it is worth analyzing the reduction in the emission of this factor as a result of changes in the type of energy source used. Different energy sources produce different amounts of carbon dioxide during combustion that is decisive for the calculation of carbon dioxide savings. For example, the combustion of lignite produces emissions that are much higher - around twice - than the combustion of natural gas. For example burning lignite produces around twice as
Table 3. $\mathrm{CO}_{2}$ emissions from various energy sources (after Quaschning [65]).

\begin{tabular}{ll}
\hline Energy source & Emission $\left[\mathrm{kg}_{\mathrm{CO}_{2}} / \mathrm{GJ}\right]$ \\
\hline Wood & 209.9 \\
Lignite & 106.0 \\
Hard coal & 94.6 \\
Heating oil & 77.4 \\
LPG & 63.1 \\
Natural gas & 55.8 \\
\hline
\end{tabular}

much carbon dioxide in relation to its energy content as burning natural gas. In the table below (Table 3) the emission of $\mathrm{CO}_{2}$ from different fuels, in relation to the primary energy content is presented.

Analyzing data presented in Table 3, we can see that for long-term climate protection, only ways to reduce carbon emissions is producing more energy from renewable sources and using fuels with lower carbon contents. According to data from the Central Statistical Office of Poland, $1.77 \%$ of households were equipped with solar collectors in 2015, and $0.08 \%$ with heat pumps [58,59]. However, solar collectors for home heating were used by only $0.14 \%$ of households, while heat pumps were the primary source of heating only in $0.03 \%$ of households. It should be emphasized that the share of solar collectors in energy consumption by households is only $0.21 \%$, and geothermal energy $0.09 \%$. In 2018, the percentage of households equipped with heat pumps increased significantly to $0.48 \%$, while in the case of solar energy the share reached $1.98 \%$. Compared to 2015, the share of heat pumps as a basic source of heating in households has become more common than solar cells: $0.15 \%$ and $0.13 \%$ respectively. Despite the upward trend, the share of these sources in home heating will not become significant in the next few years, although large funds are allocated to co-finance such investments. Presently in Poland started process of collecting data do build up the Central Emission Register of Buildings CEEB. CEEB will be used to identify sources of low emissions from buildings such as residential buildings, public buildings, including small local heating plants, production plants, warehouses, garages, farms, and even churches and hospitals. The providing information to this data base is obligatory. It is expected that data collected in CEEB will support all programmes and countermeasures to improve air quality.

\section{Conclusions}

In large cities of the TRITIA area, such as Opole, Katowice, Jastrzębie Zdrój, Ruda Śląska, more than $50 \%$ of the energy consumed for domestic heating is not connected with burning coal in domestic boilers. The source in this case is district heat. In smaller 
towns and rural districts, fossil solid fuels, wood and biomass are the dominant energy sources.

In towns with predominantly single-family housing and rural districts, the use of solid coal and wood fuels reaches about $80 \%$ of the total energy balance. Until the 2016/2017 heating season, it was allowed to burn low-quality solid fuels such as coal slurry, coal dust and flotation concentrates. In Silesia Voivodship, the share of these fuels accounted for about $5 \%$ of all fuels in 2015. The structure of the energy sources used and the continued presence of outdated coalfired boilers and cookers are the direct cause of emissions of harmful substances into the air.

Alternative energy sources such as electricity, including solar panels and heat pumps, are still marginally used. Households with such installations represent about $2 \%$ for electricity and less than $1 \%$ for solar collectors and heat pumps. Of the fuels with lower emissions, such as natural gas, LPG and heating oil, natural gas used in $13 \%$ of households is the most significant, even if system heat is included.

Statistical Office (GUS) data shows that solid fuels are most commonly used in private households. The two most important and widely used solid fuels are hard coal and firewood, while other fuels (other types of biomass, lignite, coke) are used less frequently. Hard coal and firewood are usually consumed simultaneously or interchangeably in the same boilers and cookers. Fewer households used only coal or only wood. The fuels are usually burned interchangeably, depending on current availability and price conditions and the time of year.

\section{Conflicts of interest}

None declared.

\section{Ethical statement}

The authors state that the research was conducted according to ethical standards.

\section{Funding body}

The work presented in this paper has been performed within the AIR TRITIA project (Uniform approach to the air pollution management system for functional urban areas in TRITIA region/Air Tritia), supported by the European Regional Development Fund - Interreg CENTRAL EUROPE Programme - under the Contract No. CR 1101, and by the Polish Ministry of Science and Higher Education under the Contract No. 3861/INTERREG CE/ 17/2018/2.

\section{References}

[1] World Health Organization (WHO). World Health Assembly, 69. Health and the environment: draft road map for an enhanced global response to the adverse health effects of air pollution: report by the Secretariat. WHO; 2016. Retrieved from: https://apps.who.int/iris/handle/10665/252673.

[2] World Health Organization (WHO). Ambient air pollution: a global assessment of exposure and burden of disease: WHO Regional Office for Europe. 2016. ISBN 9789241511353. Retrieved from: https://apps.who.int/iris/bitstream/handle/ 10665/252673/A69_18-en.pdf? sequence=1\&isAllowed =y. [Accessed 8 March 2021].

[3] http://www.eea.europa.eu/publications/air-quality-ineurope-2016.

[4] http://acm.eionet.europa.eu/reports/ETCACM_TP_2016_5_ AQ_HIA_methodology.

[5] http://www.euro.who.int/_data/assets/pdf_file/0006/238956/ Health-risks-of-air-pollution-in-EuropeHRAPIE-project,Recommendations-for-concentrationresponse-functions-forcostbenefit-analysis-ofparticulate-matter,-ozone-andnitrogen-dioxide.pdf.

[6] World Health Organization (WHO). Economic cost of the health impact of air pollution in Europe: clean air, health and wealth. Copenhagen: WHO Regional Office for Europe; 2015.

[7] Qu H, Chan WY, Xu A, Chung KL, Lau KH, Guo P. Visual analysis of the air pollution problem in Hong Kong. IEEE Trans Visual Comput Graph 2007;13(6):1408-15. https://doi: 10.1109/TVCG.2007.70523.

[8] Cohen A, Anderson HR, Frostad J, K Estep, et al. Estimates and 25-year trends of the global burden of disease attributable to ambient air pollution: an analysis of data from the Global Burden of Diseases Study 2015. Lancet 2017;389: 1907-18. https://doi.org/10.1016/SO140-6736(17)30505-5.

[9] Belis CA, Karagulian F, Larsen BR, Hopke PK. Critical review and meta-analysis of ambient particulate matter source apportionment using receptor models in Europe. Atmos Environ 2013;69:94-108. https://doi.org/10.1016/ j.atmosenv.2012.11.009.

[10] Karagulian F, Belis CA, Dora CFC, Prüss-Ustün AM, Bonjour S, Adair-Rohani $\mathrm{H}$, et al. Contributions to cities' ambient particulate matter (PM): a systematic review of local source contributions at global level. Atmos Environ 2015;120: 475-83. https://doi.org/10.1016/j.atmosenv.2015.08.087.

[11] Kiesewetter G, Schöpp W, Amann M. A scalable approach to modelling health impacts of air pollution based on globally available data 2016 [online]. Available from: http:// scholarsarchive.byu.edu/iemssconference/2016/Stream-A/ $80 \%$.

[12] Halkos G, Managi S, Tsilika K. Measuring air polluters' responsibility in transboundary pollution networks. Environ Econ Pol Stud 2018;20(3):619-39. https://doi.org/10.1007/ s10018-017-0208-3.

[13] Fujii H, Managi S. Economic development and multiple air pollutant emissions from the industrial sector. Environ Sci Pollut Res - Int 2016;23(3):2802-12. https://doi.org/10.1007/ s11356-015-5523-2.

[14] Halkos G, Tsilika K. Understanding transboundary air pollution network: emissions, depositions and spatio-temporal distribution of pollution in European region. Resour Conserv Recycl 2019;145:113-23. https://doi.org/10.1016/ j.resconrec.2019.02.014.

[15] Bitta J, Svozilik V, Pavlikova I, Jancik P. Air pollution dispersion modelling using spatial analyses. ISPRS Int J GeoInf 2018;7(12):489. https://doi.org/10.20944/preprints201810. 0159. 2018.

[16] Zhu C, Tian H, Hao J. Global anthropogenic atmospheric emission inventory of twelve typical hazardous trace elements, 1995-2012. Atmos Environ 2020;220:117061. https:// doi.org/10.1016/j.atmosenv.2019.117061. 
[17] Vallius M, Janssen NA, Heinrich J, Hoek G, Ruuskanen J, Cyrys J, et al. Sources and elemental composition of ambient PM(2.5) in three European cities. Sci Total Environ 2005; 337(1-3):147-62. https://doi.org/10.1016/j.scitotenv.2004. 06.018. PMID: 15626386.

[18] Koolen CD, Rothenberg G. Air pollution in Europe. ChemSusChem 2019;12(1):164-72. https://doi.org/10.1002/cssc. 201802292. 2019.

[19] Juda-Rezler K, Reizer M, Oudinet JP. Determination and analysis of PM10 source apportionment during episodes of air pollution in central Eastern European urban areas: the case of wintertime 2006. Atmos Environ 2011;45:6557-66. https://doi.org/10.1016/j.atmosenv.2011.08.020.

[20] Pascal M, de Crouy Chanel P, Wagner V, Corso M, Tillier C, Bentayeb $\mathrm{M}$, et al. The mortality impacts of fine particles in France. Sci Total Environ 2016;571:416-25. https://doi.org/ 10.1016/j.scitotenv.2016.06.213.

[21] Pokorná P, Schwarz J, Krejci R, Swietlicki E, Havránek V, Ždímal V. Comparison of $\mathrm{PM}_{2.5}$ chemical composition and sources at a rural background site in Central Europe between 1993/1994/1995 and 2009/2010: effect of legislative regulations and economic transformation on the air quality. Environ Pollut 2018;241:841-51. https://doi.org/10.1016/ j.envpol.2018.06.015. Epub 2018 Jun 14. PMID: 29909310.

[22] Pokorná P, Hovorka J, Kroužek J, Hopke PK. Particulate matter source apportionment in a village situated in industrial region of Central Europe. J Air Waste Manag Assoc 2013;63(12):1412-21. https://doi.org/10.1080/10962247.2013. 825215.

[23] Zajusz-Zubek E, Kaczmarek K, Mainka A. Trace elements speciation of submicron particulate matter (PM1) collected in the surroundings of power plants. Int J Environ Res Publ Health 2015;12:13085-103. https://doi.org/10.3390/ijerph12 1013085.

[24] Juda-Rezler K, Zajusz-Zubek E, Reizer M, Kurek E, Bulska E, Klejnowski K. Bioavailability of elements in atmospheric $\mathrm{PM}_{2.5}$ during winter episodes at Central Eastern European urban background site. Atmos Environ 2021;245:117993. https://doi.org/10.1016/j.atmosenv.2020.117993. 15 January 2021.

[25] Zajusz-Zubek E, Mainka A, Kaczmarek K. Determination of water-soluble elements in PM2.5, PM10, and PM2.5-10 collected in the surroundings of power plants. E3S Web of Conferences, vol. 28; 2018, 01042. https://doi.org/10.1051/ e3sconf/20182801042.

[26] Samek L, Stegowski Z, Furman L, Styszko K, Szramowiat K, Fiedor J. Quantitative assessment of $\mathrm{PM}_{2.5}$ sources and their seasonal variation in Krakow. Water Air Soil Pollut 2017; 228(8):290. https://doi.org/10.1007/s11270-017-3483-5. Epub 2017 Jul 21. PMID: 28794573; PMCID: PMC5522505.

[27] Rogula-Kozłowska W, Klejnowski K, Rogula-Kopiec P, Ośródka L, Krajny E, Błaszczak B, et al. Spatial and seasonal variability of the mass concentration and chemical composition of $\mathrm{PM}_{2.5}$ in Poland. Air Qual Atmos Health 2014;7: 41-58. https://doi.org/10.1007/s11869-013-0222-y.

[28] Pastuszka JS, Rogula-Kozłowska W, Zajusz-Zubek E. Characterization of PM10 and PM2.5 and associated heavy metals at the crossroads and urban background site in Zabrze, Upper Silesia, Poland, during the smog episodes. Environ Monit Assess 2010;168:613-27. https://doi.org/10.1007/ s10661-009-1138-8.

[29] Rogula-Kozłowska W, Klejnowski K, Rogula-Kopiec P, Mathews B, Szopa S. A study on the seasonal mass closure of ambient fine and coarse dusts in Zabrze, Poland. Bull Environ Contam Toxicol 2012;88:722-9. https://doi.org/10.1007/ s00128-012-0533-y.

[30] Ham WA, Kleeman MJ. Size-resolved source apportionment of carbonaceous particulate matter in urban and rural sites in central California. Atmos Environ 2011;45:3988-95.

[31] Majewski G, Rogula-Kozłowska W. The elemental composition and origin of fine ambient particles in the largest Polish conurbation: first results from the short-term winter campaign. Theor Appl Climatol 2016;125:79-92. https:// doi.org/10.1007/s00704-015-1494-y.

[32] World Health Organization (WHO), Health effects of black carbon by:Janssen NAH, Gerlofs-Nijland ME, Lanki T, Salonen RO, Cassee F, Hoek G, Fischer P, et al. WHO regional Office for Europe. 2012. https://www.euro.who. int/_data/assets/pdf_file/0004/162535/e96541.pdf 08.03.2021.

[33] Rogula-Kozłowska W, Klejnowski K. Submicrometer aerosol in rural and urban backgrounds in southern Poland: primary and secondary components of PM1. Bull Environ Contam Toxicol 2013;90:103-9. https://doi.org/10.1007/s00128-0120868-4.

[34] Harrison RM, Yin J. Sources and processes affecting carbonaceous aerosol in central England. Atmos Environ 2008;42: 1413-23. https://doi.org/10.1016/j.atmosenv.2007.11.004.

[35] Zajusz-Zubek E, Mainka A, Korban Z, Pastuszka JS. Evaluation of highly mobile fraction of trace elements in PM10 collected in Upper Silesia (Poland): preliminary results. Atmos. Pollut. Res. 2015;6(6):961-8. https://doi.org/10.1016/ j.apr.2015.05.001.

[36] Jiang M, Gao X, Guan Q, Hao X, An F. The structural roles of sectors and their contributions to global carbon emissions: a complex network perspective. J Clean Prod 2019;208:426-35. https://doi.org/10.1016/j.jclepro.2018.10.127.

[37] Kubica R, Kubica K, Kacprzyk W. Limitation of black carbon emissions from solid fuel combustion in small plants (Polish title: ograniczanie emisji sadzy ze spalania paliw stałych $\mathrm{w}$ instalacjach małej mocy). Przemys Chem 2016;95(3):472-9. https://doi.org/10.15199/62.2016.3.27.

[38] World Health Organization (WHO). Residential heating with wood and coal: health impacts and policy options in Europe and North America. WHO Regional Office for Europe; 2015.

[39] Morawska L, Afshari A, Bae G, Buonanno G, Chao C, Hänninen $\mathrm{O}$, et al. Indoor aerosols: from personal exposure to risk assessment. Indoor Air 2013;23:462-87. https:// doi.org/10.1111/ina.12044.

[40] Ward T, Noonan C. Results of a residential indoor $\mathrm{PM}_{2.5}$ sampling program before and after a woodstove changeout. Indoor Air 2008;18:408-15. https://doi.org/10.1111/j.16000668.2008.00541.x.

[41] Wong JYY, Bassign BA, Hu W, Seow WJ, Shiels MS, Ji BT, et al. Household coal combustion, indoor air pollutants, and circulating immunologic/inflammatory markers in rural China. J Toxicol Environ Health 2019;82(6):411-21. https:// doi.org/10.1080/15287394.2019.1614500. 2019.

[42] Zhang J, Smith KR. Household air pollution from coal and biomass fuels in China: measurements, health impacts, and interventions. Environ Health Perspect 2007;115(6):848-55. https://doi.org/10.1289/ehp.9479.

[43] Heidi E, Staff M, Aunan K, Seip HM. Potential health benefit of reducing household solid fuel use in Shanxi province, China. Sci Total Environ 2006;372(1):120-32. https://doi.org/ 10.1016/j.scitotenv.2006.09.007. 2006; 15.

[44] Bozkurt Z, Dogan G, Arslanbas D, Pekey B, Pekey H, Dumanoglu $Y$, et al. Determination of the personal, indoor and outdoor exposure levels of inorganic gaseous pollutants in different microenvironments in an industrial city. Environ Monit Assess 2015;187(9):590. https://doi.org/10.1007/s10661015-4816-8.

[45] Hulin M, Caillaud D, Annesi-Maesano I. Indoor air pollution and childhood asthma: variations between urban and rural areas. Indoor Air 2010;20:502-14. https://doi.org/10.1111/ j.1600-0668.2010.00673.x.

[46] Almeida SM, Canha N, Silva A, Freitas MD, Pegas P, Alves C, et al. Children exposure to atmospheric particles in indoor of Lisbon primary schools. Atmos Environ 2011;45: 7594-9. https://doi.org/10.1016/j.atmosenv.2010.11.052.

[47] Mejía JF, Choy SL, Mengersen K, Morawska L. Methodology for assessing exposure and impacts of air pollutants in school children: data collection, analysis and health effects - a literature review. Atmos Environ 2011;45:813-23. https:// doi.org/10.1016/j.atmosenv.2010.11.009. 2011. 
[48] Branco PTBS, Alvim-Ferraz MCM, Martins FG, Sousa SIV. Indoor air quality in urban nurseries at Porto city: particulate matter assessment. Atmos Environ 2014;84:133-43. https:// doi.org/10.1016/j.atmosenv.2013.11.035.

[49] Kingham S, Durand M, Harrison J, Cavanagh J, Epton M. Temporal variations in particulate exposure to wood smoke in a residential school environment, Atmos. Environ Times 2008;42: 4619-31. https://doi.org/10.1016/j.atmosenv.2008.01.064.

[50] Buonanno G, Marini S, Morawska L, Fuoco FC. Individual dose and exposure of Italian children to ultrafine particles. Sci Total Environ 2012;438:271-7. https://doi.org/10.1016/ j.scitotenv.2012.08.074.

[51] Adaji EE, Ekezie W, Clifford M, Phalkey R. Understanding the effect of indoor air pollution on pneumonia in children under 5 in low- and middle-income countries: a systematic review of evidence. Environ Sci Pollut Res 2019;26:3208-25. https://doi.org/10.1007/s11356-018-3769-1.

[52] Kurmi OP, Lam KBH, Ayres JG. Indoor air pollution and the lung in low- and medium-income countries. Eur Respir J 2012;40:239-54. https://doi.org/10.1183/09031936.00190211.

[53] Chen C, Modrek S. Gendered impact of solid fuel use on acute respiratory infections in children in China. BMC Publ Health 2018;18:1170. https://doi.org/10.1186/s12889-018-6035-z.

[54] Guercio V, Pojum IC, Leonardi GS, Shrubsole C, Gowers AM, Dimitroulopoulou S, et al. Exposure to indoor and outdoor air pollution from solid fuel combustion and respiratory outcomes in children in developed countries: a systematic review and meta-analysis. Sci Total Environ 2021;755(1):142187. https://doi.org/10.1016/j.scitotenv.2020.142187. 2021.

[55] Mainka A, Zajusz-Zubek E. Indoor air quality in urban and rural preschools in upper Silesia, Poland: particulate matter and carbon dioxide. Int J Environ Res Publ Health 2015;12: 7697-771. https://doi.org/10.3390/ijerph120707697.

[56] Błaszczyk E, Rogula-Kozłowska W, Klejnowski K, Kubiesa P, Fulara I, Mielżyńska Svach D. Indoor air quality in urban and rural kindergartens: short-term studies in Silesia, Poland. Air Qual Atmos Health 2017;10:1207-20. https:// doi.org/10.1007/s11869-017-0505-9.
[57] Fine dusts in the atmosphere. A compendium of knowledge about particulate matter pollution in Poland (Polish title: Pyły drobne w atmosferze. In: Juda-Rezler K, Toczko B, editors. Kompendium wiedzy o zanieczyszczeniu pyłem zawieszonym w Polsce). Warszawa: Biblioteka Monitoringu Środowiska; 2016. ISBN 978-83-61227-73-1.

[58] Główny Urząd Statystyczny [GUS]. Energy consumption in households in 2015 (Polish title: zużycie energii w gospodarstwach domowych w 2015 r). 2015.

[59] Główny Urząd Statystyczny [GUS]. Energy consumption in households in 2018 (Polish title: zużycie energii $\mathrm{w}$ gospodarstwach domowych w 2018 r). 2018.

[60] Act 2006. Act of August 25, 2006 on the fuel quality monitoring and scrutinizing system (Polish title: Ustawa $\mathrm{z}$ dnia 25 sierpnia 2006 r. o systemie monitorowania i kontrolowania jakości paliw). Pol. Law J. 2006;169:1200.

[61] Regulation 2018a. Regulation of the Minister of Energy of September 27, 2018 on quality requirements for solid fuels (Polish title: Rozporządzenie Ministra Energii z dnia 27 września $2018 \mathrm{r}$. w sprawie wymagań jakościowych dla paliw stałych). Pol. Law J. 2018:1890.

[62] Regulation of the Minister of Energy of September 27, 2018 on the method of sampling of solid fuels (Polish title: Rozporządzenie Ministra Energii z dnia 27 września 2018 r. w sprawie sposobu pobierania próbek paliw stałych). Pol. Law J. 2018:1891.

[63] Regulation of the Minister of Energy of September 27, 2018 on the model certificate for the quality of solid fuels. (Polish title: Rozporządzenie Ministra Energii z dnia 27 września 2018 r. w sprawie wzoru świadectwa jakości paliw stałych). Pol. Law J. 2018:1892. 2018.

[64] Regulation of the Minister of Energy of September 27, 2018 on methods for testing the quality of solid fuels. (Polish title: Rozporządzenie. 2018d. Rozporządzenie Ministra Energii z dnia 27 września 2018 r. w sprawie metod badania jakości paliw stałych). Pol. Law J. 2018:1892.

[65] Quaschning V. Regenerative Energiesystemetechnologie Berechnung - Klimaschutz. Carl Hanser Verlag GmbH \& Co. KG; 2019. ISBN: 978-3-446-46113-0. 